Article

\title{
The Evolution and Effect Evaluation of Photovoltaic Industry Policy in China
}

\author{
Ruyin Long *, Wenhua Cui and Qianwen Li
}

School of Management, China University of Mining and Technology, Da Xue Road 1, Xuzhou 221116, China; cuiwenhua21@163.com (W.C.); zzxhlqw@163.com (Q.L.)

* Correspondence: longruyin@cumt.edu.cn

Received: 13 October 2017; Accepted: 21 November 2017; Published: 27 November 2017

\begin{abstract}
The large scale of China's photovoltaic (PV) industry and the great policy support by the Chinese government make it necessary to scientifically evaluate PV industry policy. This study designed an evaluation framework for China's PV industry policy from four dimensions (policy measure, policy type, policy strength, and policy issuing department) to categorize and quantify China's 307 PV industry policies from 1994 to 2016. Furthermore, the historical evolution and realistic effect of the policies on the PV industry in China were examined. The results show that, currently, grid support, operation specification, and operation supervision are the main policy measures, while a low-level notice is the main type of policy. The policy issued strength is generally low. The enforcement strength of regional policy presents descending trend from the northern to the southern provinces, and a similar trend from coastal provinces to inland provinces. The policy for grid support, operation specification, and technical specification has had the best effect. The most effective policy types are the sector-specific notices and announcements, and the best policy-issuing department is the National Energy Administration. In terms of policy strength, the policy for grid support, operation specification, and operation supervision has had a positive correlation with the development of the industry, although it did not achieve its desired effect.
\end{abstract}

Keywords: photovoltaic industry; policy evolution; policy effect

\section{Introduction}

Solar energy is a renewable power source that is an ideal replacement for fossil fuels in the future. In recent years, the solar photovoltaic (PV) market has grown rapidly around the world. According to the data from the International Energy Agency, the average annual growth rate of PV power generation exceeded 40\% from 2006 to 2016 [1]. By the end of 2016, the new PV installed capacity reached 75 GW globally, and the cumulative PV installed capacity increased to 303 GW [1]. In China, the PV industry started in 2004. The cumulative PV installed capacity grew from $850 \mathrm{MW}$ in 2010 to 78,070 MW in 2016, and the newly-installed capacity in 2016 was 34,540 MW [2]; consequently, China's cumulative and new installed capacity are ranked first in the world [2]. Since 2004, the Chinese government has paid much attention to the development of China's PV industry, and has issued relevant industrial policy from the multiple perspectives of financial subsidies, tax incentives, technical support and grid service to encourage and support the solar PV industry.

Now, the scale of China's PV industry is leading the world, and the government still strongly supports the further development of this industry. While many problems restrict the development of the industry, the main performance obstacles are a lack of a clear borders between the government and the market and industrial regulation failure [3-5]; difficulties in grid connection, coordination, and planning problems between PV power generation and power grid construction [5-7]; lack of independent innovation capability and core technology [5,6], and a lag in technical standards [8-11]; 
international environmental deterioration, financial system flaws, risk transfer mechanism deficits, and lack of innovative financial products [6,12]; and the government blindly carrying forward the PV industry, and the abuses of financial subsidy policy [5,8,9]. On the one hand, there is continuous expansion of the operation scale and the continued investment of government policy, but on the other hand there is the difficulty in breaking through the existing technology and innovation bottleneck, both of which lead to China's PV policies being questioned. It is urgent to scientifically evaluate the implementation effect of PV industry policy in China.

Currently, some foreign studies related to the effect of the photovoltaic industry policy have been conducted. It mainly focused on specific policy measures to establish a new evaluation index of the PV market. The research mainly employed quantitative analysis methods. Dusonchet and Telaretti [13] and Sarasa-Maestro et al. [14] performed a comparative economic analysis through the main support measures (feed-in tariffs and tradable green certificates) implemented in Western EU countries, based on the calculation of the cash flow, the net present value and the internal rate of return indices, which can assess the effectiveness of PV energy policies in different Western European member states. Shrimali and Jenner [15] assessed the effectiveness of 12 state-level policies on the cost and deployment of solar photovoltaic, it showed that cash incentives and tax incentives would increase the initial cost commercial system deployment and reduce the initial cost of PV installation. The similar studies have been found in the research of Sarzynski [16] and Kwan [17]. Most Chinese studies on PV industry policy are mainly qualitative analyses and case studies. Zhang et al. [18] examined the similarities and differences between the development trajectories of wind power and solar PV power in terms of development status, development policy, and development trends. Zhi et al. [4] examined the development history of China's PV industry policy system from the perspective of industrial policies, and conducted a comparative analysis among China, United States, Germany, and Japan from the perspective of both the supply- and demand-side policies. There are few Chinese studies on the effect of PV industry policy available. Some studies considered policy factors to analyze the economic benefits of photovoltaic industry $[19,20]$ and some scholars have studied the effectiveness of incentive policies of PV industry [21-23]. However, based on the limited studies on China's PV policies, the literature only focuses on a group of photovoltaic industry policy and the logic analysis, which cannot explain the China's PV policies and its relation to the development of the industry. The studies consider policy to discuss China's photovoltaic industry policy measures, policy types and policy strength, which is missing. There is also a lack of a systematic photovoltaic policy system to study the evolution and effect of China's photovoltaic industry policy.

This paper attempts to construct an evaluation system of China's PV industry policy based on four dimensions: the policy measures, policy types, policy strength, and policy issuing departments. Then, according to the evaluation framework, we categorize and quantify China's PV industry policies, and analyze the historical evolution and implementation effect of these policies based on the four dimensions. Lastly, we propose some suggestions to enhance the effectiveness of China's PV industry policy and improve future industrial policy.

The rest of this paper is organized as follows: Section 2 introduces the design theory of the evaluation system; research methods are introduced in Section 3; Section 4 analyzes the evolution of China's PV industry policy and evaluates the effect of China's PV industry policy; and Section 5 provides conclusions and policy implications.

\section{Design Theory of Evaluation System}

There is an increasing amount of research on the effects of policy, and most studies are based on the analysis of the effect of policy instruments. Rothwell and Zegveld [24] analyzed technical innovation policies from three dimensions (demand, supply, and environmental instrument), and many scholars since have enriched the three-dimensional evaluation framework and applied it to study the performance of policy instruments. For example, Amp and Francis [25] considered the influence of the types and fields of scientific and technological activities to construct a three-dimensional 
framework of public science and technology policy, and used it to study the science and technology policy system. Su et al. [26] built a two-dimensional analysis framework of China's innovation policy, and studied the role of China's innovation policy in promoting the new-energy vehicles industry by combining the three-dimensional policy instrument with the innovation value chain (i.e., research and development, industrialization and marketization). Li and Wang [7] constructed a two-dimensional analysis framework of China's PV industry policy and analyzed the existing problems of these policy instruments by combining the three-dimensional policy instrument with life cycle theory of industrial development.

Research on the effect of policy should avoid an analysis that considers only the perspective of the policy instrument. Rather, an acceptable analysis should combine several aspects, such as policy strength, policy objective, and the policy-issuing department. Breslin [27] quantified central and local governments' foreign direct investment policies from 1978 to 2000, and empirically studied the effectiveness of China's foreign direct investment policies on the basis of the policy measures dimension. However, the selection of policy measures was limited and the study did not consider policy strength. Huang [28] analyzed the historical evolution of China's 1980-2005 innovation policy on the basis of policy strength and policy type. However, the study was only a descriptive statistical analysis of innovation policy, and it did not involve a study of policy content. Peng et al. [29] quantified China's technological innovation policy on the basis of policy strength, policy measure, and policy objective, and studied the evolution path and performance of China's technological innovation policy. Wang et al. [30] combined policy content with policy strength in their research of China's wind power industry policy, and considered policy departments and the form of policy formulation.

At present, there is no systematic evaluation framework for analyzing the effects of policy, but evaluations from the perspective of policy instruments or means are common. In addition, Schneider and Ingram [31] thought that the research on the effect of policy should be studied on the basis of the policy objective, policy implementer and policy measures. Peters [32] believed that, in addition to considering the policy instruments, research to analyze and evaluate government policy needs to include policy issues and policy management.

Learning from the above literature, we concluded that an evaluation framework for examining the effect of policy should cover three dimensions: policy means (or measures), policy types and policy strength. In addition, according to Wang et al. [30], an evaluation framework also should consider the policy issuing department. Thus, we constructed the framework for evaluating the effect of China's PV industry policy based on four dimensions: the policy measure, policy type, policy strength, and policy issuing department.

\section{Research Methodology}

\subsection{Sorting and Quantifying China's Photovoltaic Industry Policy}

Policies regarding the PV industry were collected from the Law Information Database of Peking University [33]. These were retrieved using key words, such as 'photovoltaic', 'solar energy', and 'renewable energy' to search the full text of policies and regulations and identify the policy text most closely related to the PV industry. Finally, to ensure the integrity and accuracy of the policy text, we supplement the PV industry policies and regulations by examining the websites of the government departments that issued the policy.

Furthermore, to ensure the representativeness of the selected policies and regulations, selection was based on the following criteria: (1) select national and regional PV industry policies issued at the provincial level and above; (2) select only policies that are closely related to the PV industry policy (thus excluding policies that refer to renewable energy); (3) consider the main types of policies to be laws, regulations, and normative documents; and (4) select policy texts that were issued before 31 December 2016. 
A total of $307 \mathrm{PV}$ industry policies were selected for evaluation (Appendix B). 173 regional policies are included. These were organized and quantified according to promulgation time, promulgation department, policy type, legal validity and policy measures. Since the research objective was the policy variable, the content validity of the final policy quantification can be guaranteed.

\subsubsection{Policy Measure}

According to the difference of the Chinese government's roles in the PV industry policy, the PV industry policy measures were divided into four types: guidance policy measures, supporting policy measures, specification policy measures, and supervision policy measures (hereinafter referred to as guidance measures, supporting measures, specification measures, and supervision measures, respectively). These four aspects encompass a total of 14 small groups as shown in Figure 1. We used the binary method to code the virtual variables for the policy measure dimension. If a policy adopted a policy measure, the value of the corresponding variable was assigned a value of 1 ; otherwise, it was assigned 0 . Considering that a single policy may have adopted a variety of policy measures, each policy measure involved in the policy was assigned a value of 1 , while other variables that were not involved were assigned a value of 0 .

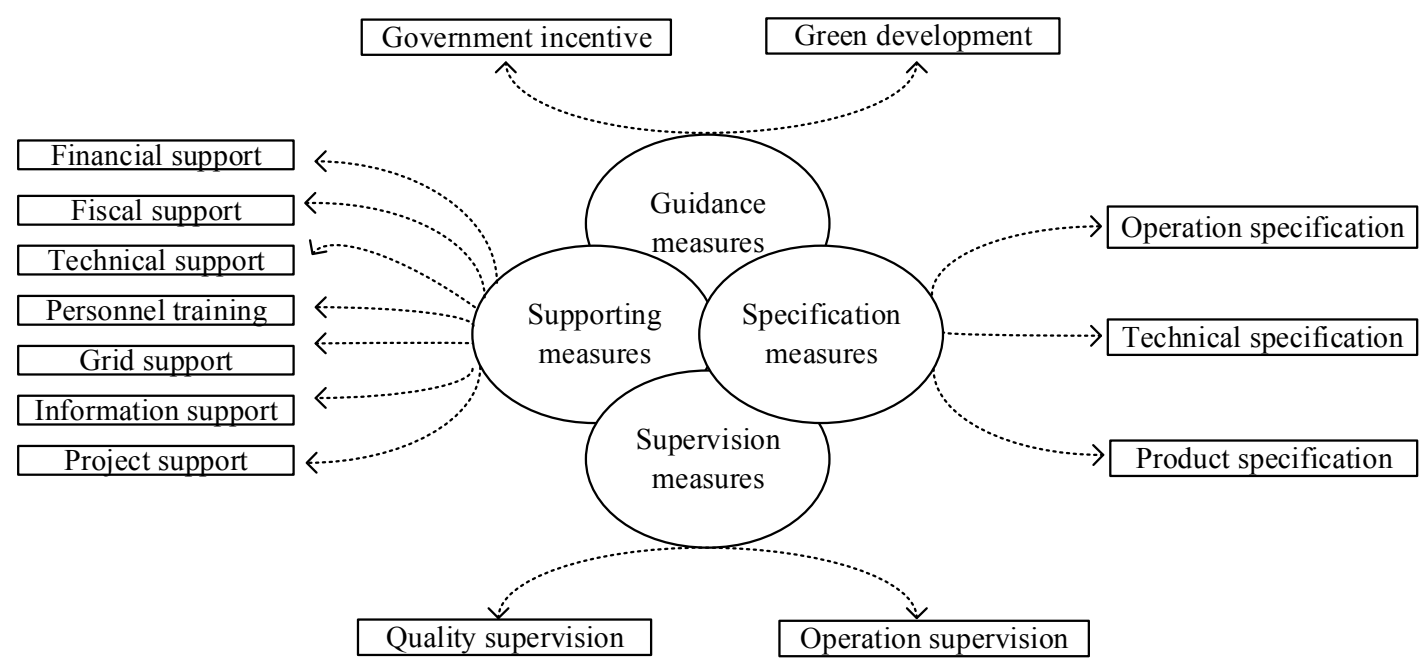

Figure 1. The classification of photovoltaic (PV) industry policy measures.

\subsubsection{Policy Type}

Although laws and policies are different, they are interrelated. Policy and law both have an impact on the development of the photovoltaic industry, but the impact efforts and angles are different. Therefore, in this dimension, the law is incorporated into the research as a formalized and standardized policy form. We referred to Peng et al. [29] when quantifying the types of technological innovation policies. The paper adopts the five-level rating assignment method for the policy type of photovoltaic industry based on the different administrative power structure of the policy enacting department. The scoring standard is: (5) laws promulgated by the National People's Congress and its Standing Committee ("Laws" for short); (4) regulations issued by the State Council and the orders of Ministries ("Regulations and Orders" for short); (3) interim regulations, decisions, opinions, and rules promulgated by the State Council, as well as the regulations, rules, and decisions of Ministries ("Opinions and Rules" for short); (2) opinions, outlines, planning, measures, and interim provisions ("Measures" for short); and (1) notices.

In our classification, the higher the level of the policy type, the higher its corresponding score. Considering that a policy might have been jointly issued by a number of departments, the score was calculated based on the best match between the issuing department and policy type. 


\subsubsection{Policy Strength}

The policy strength dimension refers to the ideas of Wang et al. (2016) [30] about establishing a standard for policy strength. We scored the PV industry policies according to implementation strength. According to differences in the level of detail and implementation strength of the 14 policy measures that were examined, we used a five-grade scoring method for each policy. The more detailed policy measures and those with greater implementation strength were assigned higher scores (Appendix A). The table in Appendix A was compiled by a professor who had studied the photovoltaic industry. Each policy was evaluated by three experts who independently scored the policies according to the table in Appendix A. When scoring was completed, the experts comparison-tested the results. Finally, the results were collated by two graduate students.

Policy strength has a specific time continuity. The policy measures not only affect the PV industry in the year of promulgation, but accumulate in their effect over time until they are repealed. We drew on Peng et al. [29] and classified the strength of PV industry policy on the basis of "issued" strength (Equation (1)) and "enforcement" strength (Equation (2)). In Equation (1), $R P_{i}$ represents the issued strength of the photovoltaic industry policy in year $i$, while in Equation (2) $A P_{i}$ represents the enforcement strength of the PV industry policy in year $i$. In both equations, $i$ represents the year ( $i \in$ postive real number set $R^{+}$) and $j$ represents the PV industry policy $\left(j \in R^{+}\right), \mathrm{A}_{i j}$ represents the policy strength of the PV industry policy $j$ issued in year $i\left(A_{i j} \in\{1,2,3,4,5\}\right), \mathrm{B}_{i j}$ represents the corresponding value of the policy type of PV industry policy $j$ which is issued in year $i\left(B_{i j} \in R^{+}\right)$, and $N_{i}$ represents the number of PV industry policies issued in year $i$ :

$$
\begin{aligned}
& R P_{i}=\sum_{j=1}^{N_{i}}\left(A_{i j} \times B_{i j}\right) \\
& A P_{i}=R P_{i-1}+R P_{i}
\end{aligned}
$$

\subsubsection{Policy Issuing Department}

Many departments are involved in the study of the PV industry policy, and there are subordinate relations and historical evolution problems between departments. These factors increase the difficulties of researching the policy departments of China's PV industry. We considered the departments that still existed in 2016. Since the State Council (SC) and the National Development and Reform Commission (NDRC) are the authorities of PV policy, the National Energy Administration (NEA) is the sector that issued the largest number of the PV industry policies. We chose only these three representative departments for issuing of PV industry policy. The remaining departments as other departments, and it has no specific number differences in other departments (OD). As for other dimensions, we used a binary method ( 0 or 1$)$ for assigning virtual variables for the policy issuing department dimension. Considering the policies may be jointly promulgated by multiple departments, each department involved in issuing a policy was assigned a value of 1 , and the other departments that were not involved in the policy were assigned a value of 0 .

\subsection{Data Resource}

In order to test the effect of PV industry policy on industrial development, we made a regression analysis to the four dimensions (policy measures, policy types, policy strength, and policy issuing department). The policy data came from the $307 \mathrm{PV}$ industry policies that were quantified as described in Section 3.1. Typically, the installed capacity and generating capacity of renewable energy sources are used to evaluate the effect of renewable energy policies [34,35]. We chose the new PV installed capacity as the index of the effect of PV industry, and the original data were first processed using a logarithm so as to avoid the interference caused by the original data units and the difference of magnitude in the original data. The new PV installed capacity data were obtained from the BP Statistical Review of World Energy 2017 [2]. 


\section{Results}

\subsection{Evolution of Policy Measures}

As shown in Figure 2, the five most important contributions to the enforcement strength intensity of policy measures for the national PV industry are government incentive, grid support, operation supervision, technical support, and fiscal support. In the early stage of China's PV industry, the government mainly issued incentive policies and gave technical supports to enhance the innovation capacity and provide "soft" power for the development of the industry. The government continues to provide substantial financial and tax support for the PV industry, which are important forces to stimulate the development of the industry.

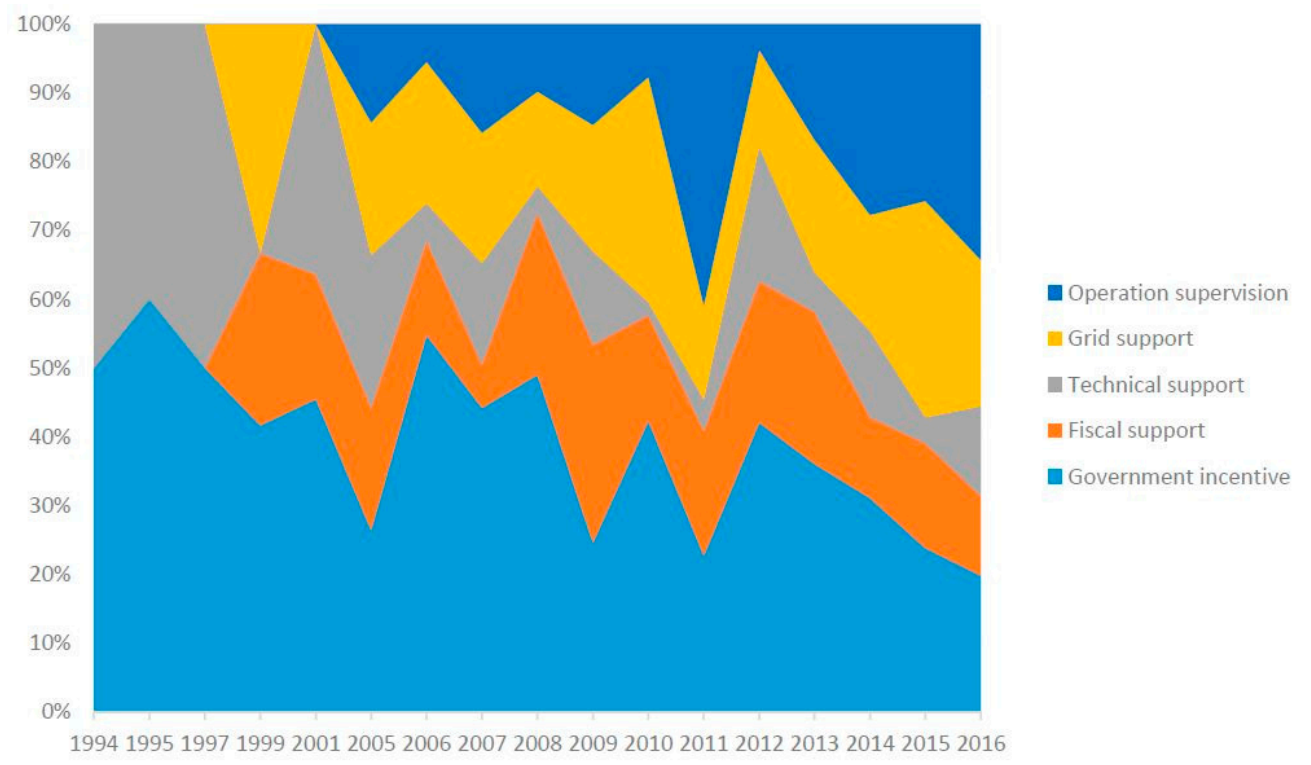

Figure 2. The main national-level policy measures of China's photovoltaic industry.

Since the promulgation of the 'renewable energy law' in 2005, the Chinese government has gradually realized the urgency of solving the grid connection problem in China's PV industry. Then it issued a series of policy measures to solve the problem. In 2011, the NDRC issued a 'Notice on improving the feed-in tariff policy of solar photovoltaic power generation'. The NDRC made a unified national solar photovoltaic benchmark tariff, which has had landmark significance for domestic PV applications. In 2013, the SC issued 'Opinions on promoting the healthy development of photovoltaic industry', which resulted in some policy measures to further support the applications of PV power generation in terms of price, tax, subsidies, grid connection and other aspects. The grid problem has been alleviated to some extent, but a complete solution to this problem is still far away.

In addition, with the rapid development of the PV industry, non-standard operation in the industry gradually emerged, such as overcapacity in the polysilicon industry, the serious phenomenon of abandoning light and power in some areas, and the disorderly operation of PV power stations. These problems still restrict the development of the PV industry. Therefore, policy measures of the Chinese government mainly focus on the operation specification and supervision of the PV industry that have developed in recent years.

In terms of regional policy measures, the five most important contributions to the enforcement strength intensity of policy measures for the regional PV industry are government incentive, fiscal support, financial support, grid support, and technical specification (Figure 3). Regional PV policy can be promulgated later. Similar to the national-level PV policy, the regional policies put more emphasis on government incentive, fiscal support policy to promote the development of the PV 
industry. Regional governments pay more attention to the photovoltaic power grid problem, which provides a great deal of grid support. Currently, compared with the national-level policy, the regional policy focuses more on the establishment and improvement the industrial standard system.

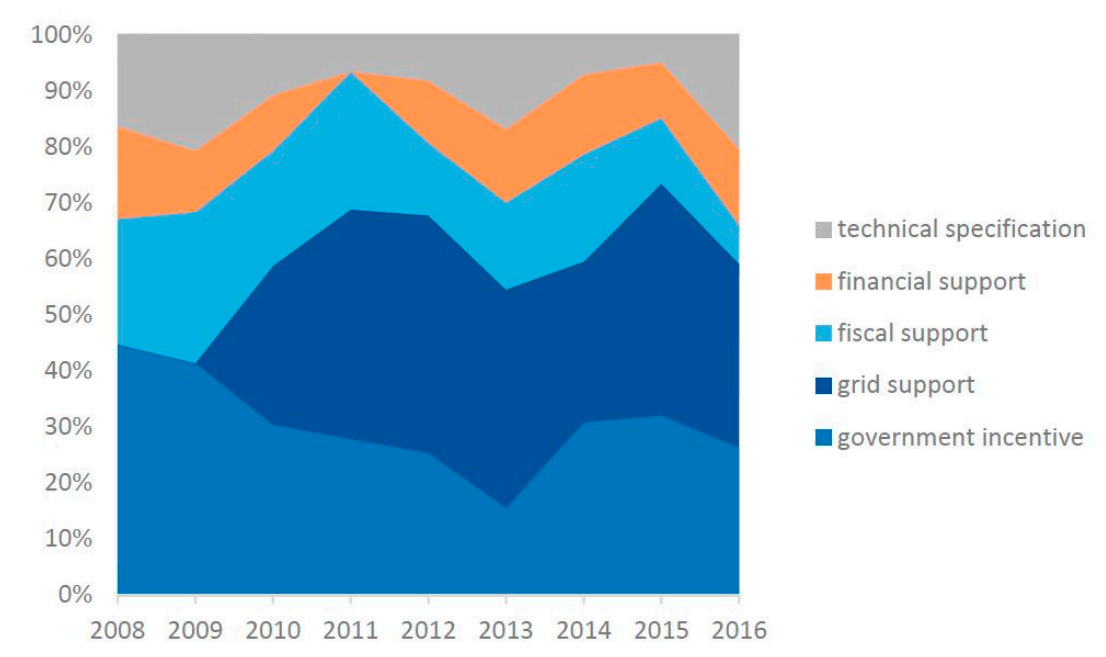

Figure 3. The main regional policy measures of China's PV industry.

\subsection{Evolution of Policy Types}

As Table 1 shows, most of the 307 policies examined were promulgated in the form of low-level notices, opinions, and measures. The value assigned to these policies is 1 and the quantity is relatively large; in contrast, the quantity of higher assignment policies is relatively small. This reflects a lack of authority in China's PV industry policies. The development of China's PV industry is immature. The government has adopted a large number of low-level, low-strength supporting measures, while the industry lacks powerful specification and supervision measures. Thus, these policy measures have failed to achieve the desired implementation effect.

Table 1. The main policy types of China's PV industry.

\begin{tabular}{cccccc}
\hline Notices & Measures & Opinions and Rules & Regulations and Orders & Laws & Sum \\
\hline $228(149)$ & $59(20)$ & $15(4)$ & 1 & 4 & 307 \\
\hline \multicolumn{5}{c}{ Note that the figures in parentheses are the number of regional policy. }
\end{tabular}

\subsection{Evolution of Policy Strength}

\subsubsection{Evolution of National-Level Policy Strength}

The PV industry policy measures not only affect the industry in the promulgation year, but also have an accumulative effect until they are repealed. Therefore, as described in Section 3.1.3, the strength of the PV industry policies was based on the issued strength and the enforcement strength.

As Figure 4 shows, the average number of China's PV industry national-level policies issued per year was 1.4 items from 1995 to 2004, but was zero in some years. It can be seen that the issuing of China's PV industry policy lacks continuity, which is related to the background of the reform of government institutions during the study period. Since 2005, the government has gradually attached importance to the development of the PV industry, and the number of PV industry policies issued by relevant institutions has been growing rapidly, especially from 2007 to 2009 and from 2012 to 2016 . In 2005, the government promulgated the 'Renewable Energy Law of the People's Republic of China', which provides the relevant legal basis for the development of the PV industry in China. On this basis, the number of guidance, supporting, specification, and supervision policies has grown rapidly, and the PV industry has developed rapidly. 


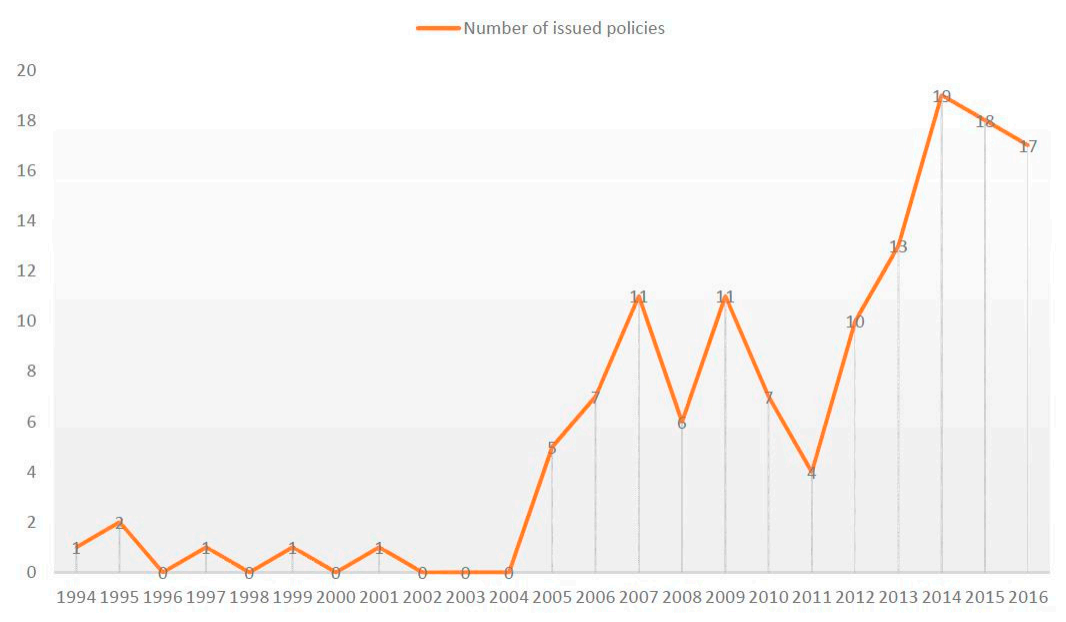

Figure 4. The number of China's photovoltaic industry national-level policies.

In 2011, China's PV industry suffered from the anti-dumping and countervailing trade policies of Europe and the USA. To cope with the impacts of the international market, the government promulgated a series of policies, such as the feed-in tariff and distributed PV power generation policy, to stimulate the domestic PV applications market. Furthermore, in the 'Paris Agreement' of 2015, the Chinese government pledged that the proportion of non-fossil fuels used in China will increase to $20 \%$ in 2030, and that China will pay more attention to the utilization of renewable energy, especially solar energy. This agreement will accelerate the promulgation of PV industry policies in China.

The strength of China's PV industry national-level policy is also increasing (Figure 5). China's PV industry only began in the ten years from 1995 to 2004. In this period, the government did not consider solar PV energy as an important strategic resource to develop and utilize. Rather, the Chinese government was just trying to learn from foreign experience, and the issued strength and enforcement strength of PV industry national-level policy were both low. Since 2005, the government has paid considerable attention to the development of the PV industry. The competent departments of the PV industry (such as the NEA and the NDRC), promulgated a series of policies to promote the development of the photovoltaic industry. The number of policies promulgated has steadily increased; meanwhile, the issued strength and enforcement strength of PV industry national-level policy has remained in a rapid uptrend.

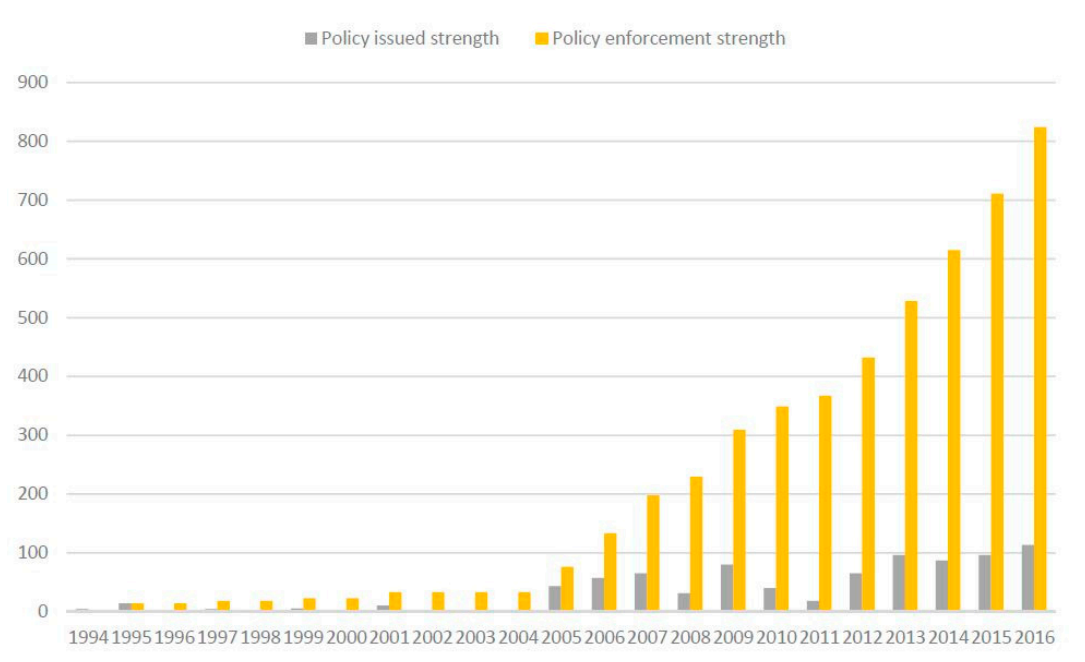

Figure 5. Issued strength and enforcement strength of China's PV industry national-level policies. 


\subsubsection{Evolution of Regional Policy Strength}

The research on the policy effectiveness in Chinese photovoltaic industry was conducted from the perspective of region distribution dimension. First, we selected the regional photovoltaic industry policy text of each province. Second, we used the method in Section 3.1.3 to quantify the regional photovoltaic industry policy. Then, we processed the policy data to obtain the issued strength of the regional photovoltaic industry policy. Finally, we obtained the enforcement strength of the regional photovoltaic industry policy.

In order to study the enforcement strength of regional photovoltaic industry policy, the research presents the regional photovoltaic policy strength classification map (Figure 6). Ranking by the regional policy enforcement strength, the top three are the Beijing-Tianjin-Hebei region, Gansu Province, and Qinghai Province. According to the policy enforcement strength of the photovoltaic industry, it is broadly divided into the following five parts:

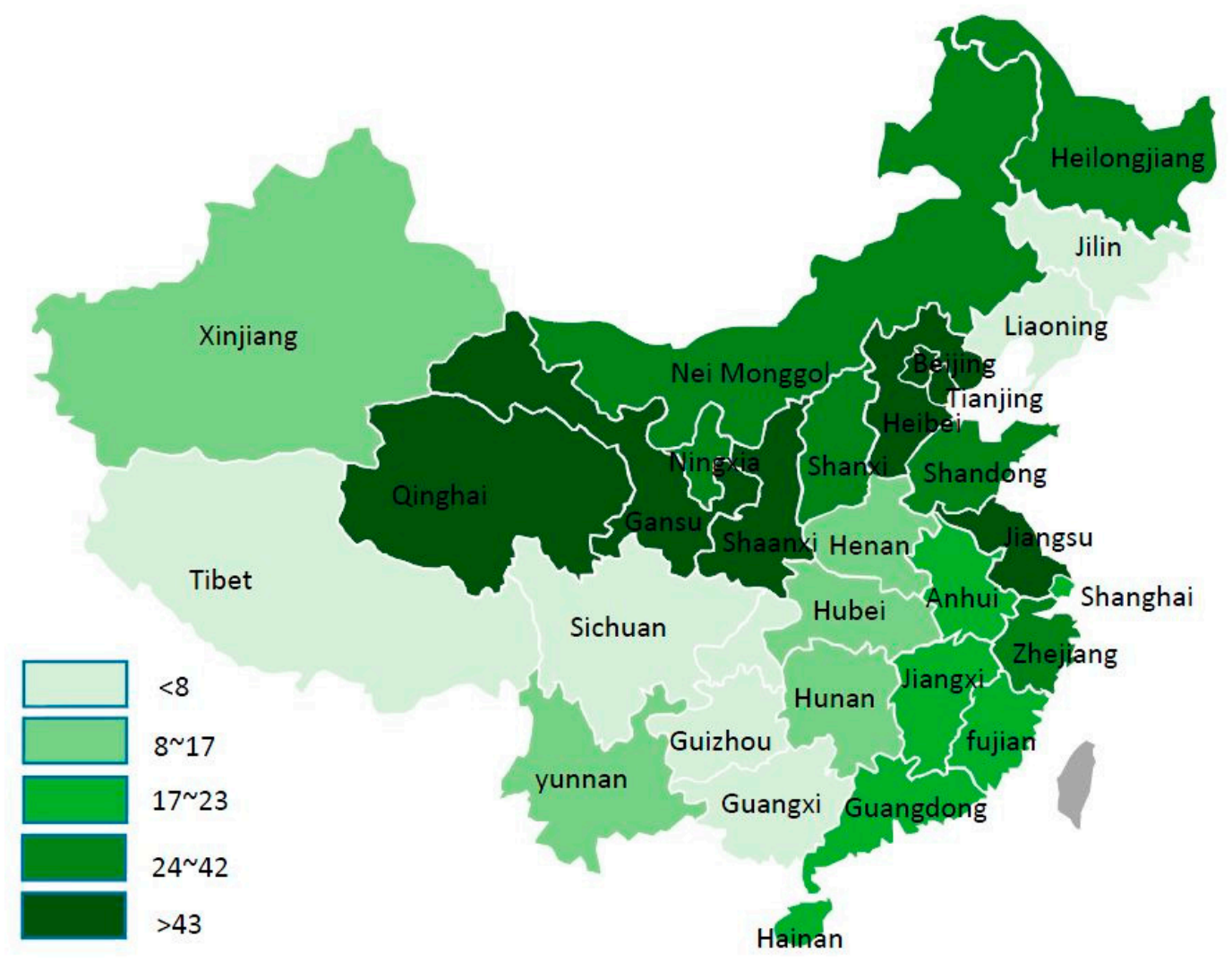

Figure 6. The regional photovoltaic policy strength classification map.

The highest-level regions are Beijing-Tianjin-Hebei region, Gansu, Qinghai, Jiangsu and Shaanxi Province; the second-level regions are Nei Monggol, Heilongjiang, Shandong, Shanxi, Zhejiang and Ningxia Province; the third-level regions are Shanghai, Anhui, Jiangxi, Guangdong, Fujian and Hainan Province; the fourth-level regions are Yunnan, Chongqing, Xinjiang, Hubei, Hunan and Henan Province; and the lowest-level regions are Liaoning, Jilin, Guangxi, Guizhou, Sichuan, and Tibet.

According to the regional photovoltaic policy strength classification map, the enforcement strength of regional policy presents descending trend from the northern to the southern provinces, and the similar trend from coastal provinces to inland provinces can be seen. 


\subsection{Evolution of Policy Issuing Departments}

As Table 2 shows, the number of government agencies involved in promulgating PV industry policy in China has increased since 1994. By 2016, more than 20 agencies have become involved in the promulgation of PV industry policies, such as National People's Congress, the SC, the NDRC, the Ministry of Finance (MOF), the NEA, and the Ministry of Industry and Information Technology. Most of the PV industry policy is promulgated by the NEA, followed in order by the NDRC and the MOF. The NEA and NDRC are the planning agencies for the PV industry, and are responsible for the development planning and strategy of the industry. The MOF is the capital guarantor for industrial development, and (as a ministerial department) shows that government pays much attention to the development of $\mathrm{PV}$ industry from the strategic planning perspective, giving the industry rich financial support. In terms of the regional policy issued departments, the provincial Development and Reform Commission and the provincial government are the main policy-issuing departments. The Construction Committee, Finance Bureau, and Price Bureau help guide the development of the photovoltaic industry.

Table 2. Policy-issuing departments and the number of policies issued by the department.

\begin{tabular}{|c|c|c|c|}
\hline Apartment & Number of Issued Policies & Apartment & Number of Issued Policies \\
\hline \multicolumn{4}{|c|}{ National-level policy department } \\
\hline 1994MOPI & 1 & 2009SAC & 1 \\
\hline 1995NDRC & 34 & 2009AQSIQ & 2 \\
\hline 1995SSTC & 1 & 2009NEA & 43 \\
\hline 1995SETC & 2 & 2009MOFCOM & 1 \\
\hline 1995NPC & 4 & 2009SAT & 3 \\
\hline 1999MOST & 4 & 2012GOASC & 1 \\
\hline 2005SC & 16 & 2013CDB & 2 \\
\hline 2005MOC & 6 & 2013MIIT & 5 \\
\hline 2006MOF & 27 & 2014SAIC & 1 \\
\hline 2007SERC & 5 & 2014APDOSC & 2 \\
\hline 2007GAC & 1 & 2015SAWS & 1 \\
\hline 2008MOHURD & 7 & 2015SFA & 1 \\
\hline 2009CNCA & 10 & 2015MOLR & 1 \\
\hline \multicolumn{4}{|c|}{ Regional policy department } \\
\hline PDRC & 127 & PG & 48 \\
\hline $\mathrm{CC}$ & 25 & $\mathrm{FB}$ & 63 \\
\hline PB & 54 & PEA & 8 \\
\hline
\end{tabular}

Note that the date before the name of the institution represents the year of the first policy issued by the institution. Ministry of Power Industry (MOPI), National Development and Reform Commission (NDRC), State Scientific and Technological Commission (SSTC), State Economic and Trade Commission (SETC), National People's Congress(NPC), Ministry of Science and Technology (MOST), The State Council (SC), Ministry of Construction (MOC), Ministry of Finance (MOF), State Electricity Regulatory Commission (SERC), General Administration of Customs (GAC), Ministry of Housing and Urban-Rural Development (MOHURD), Certification and Accreditation Administration (CNCA), Standardization Administration of the People's Republic of China (SAC), State General Administration of the People's Republic of China for Quality Supervision and Inspection and Quarantine (AQSIQ), National Energy Administration (NEA), Ministry of Commerce (MOFCOM), Government Offices Administration of the State Council (GOASC), China Development Bank (CDB), State Administration of Taxation (SAT), Ministry of Industry and Information Technology (MIIT), State Administration for Industry and Commerce (SAIC), Aid-the-Poor Development Office of the State Council (APDOSC), State Administration of Work Safety (SAWS), State Forestry Administration (SFA), Ministry of Land and Resources (MOLR), Provincial Development and Reform Commission (PDRC), Provincial Government (PG), Construction Committee (CC), Finance Bureau (FB), Price Bureau (PB), Provincial Energy Administration (PEA).

The Ministry of Housing and Urban-Rural Development (MOHURD) first participated in the promulgation of PV industry policy in 2005. In 2009 MOHURD, in 'Implementation Opinions on accelerating the construction of applications of solar photovoltaic in buildings', mentioned several actions for solving the shortage of domestic application of photoelectric products and photovoltaic grid-connecting problems. These actions included organizing a demonstration project of a photoelectric building application, implementing the 'solar roofs plan', and actively promoting the PV building 
demonstration. The combination of PV power generation and building energy conservation is the future development direction of the PV industry, and MOHURD will play an important role in its development. In 2015, the Ministry of Land and Resources issued a 'Notice on control indicators of photovoltaic power station project land' that compiled a standard for PV power generation project land. The Ministry also proposed that project construction should give priority to the use of advanced-technology and high-efficiency PV modules, improve land-use efficiency, and standardize the construction of PV power stations. In 2015, the State Forestry Administration issued the 'Notice on issues of the use of forest land in the construction of photovoltaic power stations', which stated that the construction of PV power stations should use forest land legally to avoid the destruction of ecological resources.

Over time, more agencies have become involved in promulgating PV industry policy. The agencies are not restricted to several competent authorities, because more related agencies have become involved in the construction of the PV industry. On the one hand, the diversity of policy-issuing authorities shows that the Chinese government is paying more attention and trying to promote the rapid development of China's PV industry by various forces. On the other hand, this diversity reflects that, in the process of rapid development, problems of the PV industry are not being taken seriously and solved in a coordinated and timely way. The competent authorities are unable to solve the problems independently and need the help of related agencies for a comprehensive solution.

\subsection{Evaluation of the Effect of Polices}

To determine the contribution of PV industry policy on PV installed capacity, we made a regression analysis to the four dimensions (policy measures, policy types, policy strength, and policy issuing department) and ignoring the study of the constant term. The policy strength of the photovoltaic industry includes national-level policy strength and regional policy strength. The regional policy strength will be given the weight on the proportion of the regional PV installed capacity in the China's PV installed capacity. The regression results are shown in Tables 3-6.

Table 3. Evaluation of the effect of policy measures on China's photovoltaic industry.

\begin{tabular}{cccc}
\hline Variable & Coefficient & Variable & Coefficient \\
\hline GI & $4.583(1.316)$ & IS & $0.809(1.883)$ \\
GD & $1.679(1.699)$ & PS & $-0.004(2.027)$ \\
FS & $-0.914(2.511)$ & OS & $5.561(1.554)$ \\
FIS & $1.146(3.364)$ & TSP & $4.680(0.859)$ \\
TS & - & PSP & $-1.875(1.554)$ \\
PT & $1.243(2.566)$ & QS & $3.977(1.043)$ \\
GS & $4.419(3.112)$ & OSU & $4.308(0.889)$ \\
\hline
\end{tabular}

Note that the figures in parentheses are standard errors. GI represents government incentive, GD represents green development, FS represents financial support, FIS represents fiscal support, TS represents technical support, PT represents personnel training, GS represents grid support, IS represents information support, PS represents project support, OS represents operation specification, TSP represents technical specification, PSP represents product specification, QS represents quality supervision, and OSU represents operation supervision.

Table 4. Evaluation of the effect of policy types on China's photovoltaic industry.

\begin{tabular}{cccc}
\hline Variable & Coefficient & Variable & Coefficient \\
\hline Notices & $3.307(0.635)$ & Regulations and Orders & $-0.472(1.455)$ \\
Measures & $0.245(0.669)$ & Laws & $-0.650(0.738)$ \\
Opinions and Rules & $1.381(0.688)$ & $R^{2}$ & 0.938 \\
\hline
\end{tabular}

Note that the figures in parentheses are standard errors. 
Table 5. Evaluation of the effect of policy strength on China's photovoltaic industry.

\begin{tabular}{cccc}
\hline Variable & Coefficient & Variable & Coefficient \\
\hline GI & $1.972(0.348)$ & IS & $-1.848(1.281)$ \\
GD & $-0.497(0.615)$ & PS & $0.233(0.344)$ \\
FS & $0.47(0.694)$ & OS & $0.746(0.854)$ \\
FIS & $2.620(1.300)$ & TSP & $2.888(0.459)$ \\
TS & $1.187(1.093)$ & PSP & $-0.1060(0.958)$ \\
PT & $-0.844(0.485)$ & QS & $1.179(0.879)$ \\
GS & $0.324(1.092)$ & OSU & $1.864(0.446)$
\end{tabular}

Note that the figures in parentheses are standard errors. GI represents government incentive, GD represents green development, FS represents financial support, FIS represents fiscal support, TS represents technical support, PT represents personnel training, GS represents grid support, IS represents information support, PS represents project support, OS represents operation specification, TSP represents technical specification, PSP represents product specification, QS represents quality supervision, and OSU represents operation supervision.

Table 6. Evaluation of the effect of policy issuing departments on the China's photovoltaic industry.

\begin{tabular}{cccc}
\hline Variable & Coefficient & Variable & Coefficient \\
\hline SC & $2.993(1.321)$ & NEA & $3.420(1.408)$ \\
NDRC & $0.435(1.288)$ & OD & $1.478(1.182)$ \\
$R^{2}$ & 0.933 & & \\
\hline
\end{tabular}

Note that the figures in parentheses are standard errors and similarly hereinafter. OD represents other departments.

As shown in Table 3, four major types of PV industry policy measures and the development of the PV industry have positive correlation, but the effect of each is different. In the guidance measures, government incentive have a significant positive correlation with the development of the industry, but government incentive (4.583) with real function is more effective than green development (1.679). Among supporting measures, grid support can best promote the development of the PV industry, followed by fiscal support and information support. The effects of financial support, technical support, and project support policies are not satisfactory. The unsatisfactory effect of these policies is related to the late start of each policy; thus, the policies need to be further strengthened and improved. Among specification measures, operation specifications and technical specifications have significant positive correlation with the development of China's PV industry. These results show that strengthening the internal specifications of the PV industry is very important, in addition to strengthening external incentive measures such as grid support. Among supervision measures, quality supervision policies and operation supervision policies (but especially the latter) have positive correlations with the development of China's PV industry. These findings further indicate that the internal specification, supervision, and management of the PV industry are core aspects of the PV industry and crucial to its development.

Results presented in Table 4 show that the three policy types have positive correlation with the development of China's PV industry, but their effects differ. Although the highest-level policy type is a law, it is not the most effective; rather, the most effective form of policy is the minimum-level notice. These findings could be because the government has adopted more moderate policy combinations. In addition, the policy issuing departments should promulgate the more authoritative PV industry policies (such as interim regulations, opinions, and planning of the State Council and regulations of the ministries) (1.381), and attempt to avoid issuing the less-serious industrial policies (such as opinions, outlines, planning, measures, and interim provisions) (0.245). The current status of policy types for the Chinese PV industry is related to the immaturity of the industry. The promulgation of the Renewable Energy Law and other related laws provides legal supports for the development of the PV industry in China, but did not match the rapid development of the industry; yet, this law did not have the greatest effectiveness among the policies examined. Thus, it is particularly important to accelerate the formulation of relevant laws for China's photovoltaic industry. 
The regression results of policy strength shown in Table 5 are similar to those for policy measures shown in Table 3. The similarity occurs because policy measures and policy strength are closely related, and a non-zero value for a policy measure automatically results in a non-zero value for policy strength. Among policy measures, those for fiscal support, technical specifications and operation supervision have positive correlation with the development of the PV industry in China. However, from the regression results of policy strength, the effects of grid supports and operation specifications have not reached their anticipated importance. Unilaterally increasing grid support and operation specification policies cannot achieve the desired incentive effect. In addition, the regression coefficient of operation specifications and is particularly low. These results indicate that the departments involved in issuing PV policy have no incentive to promote operation specification (0.746), especially in terms of increasing the level of government encouragement (1.972). Policies for China's PV industry are promulgated frequently, but specification policies often are not implemented, nor do they achieve the expected goal. As a result, the implementation of gird support, specification, and supervision policies for China's PV industry is slow.

The regression results regarding policy departments are presented in Table 6, and show that the PV industry policies promulgated by various departments have positive correlation with the development of PV industry. However, the NDRC, as the competent and supervision department of the PV industry, did not have significant correlation with the development of the PV industry; in fact, their performance was even worse than that of the MOHURD, State Forestry Administration, Ministry of Commerce, and other less important functional departments. In the future promulgation process of PV industry policies, the SC should focus on setting the tone of the policies. Furthermore, as a communication bridge between the SC and the NEA, the NDRC should strengthen its power, control the promulgation of policies, and exercise further macro-control over the development of the entire industry. The reorganized NEA should implement specific measures to promote the development of the PV industry, and be responsible for the SC and the NDRC.

\section{Conclusions and Policy Implications}

\subsection{Conclusions}

In recent years, China's PV industry has developed rapidly, and the number of PV industry policies has increased obviously. However, relevant research on the historical evolution and effect evaluation of PV industry policy is lacking. We designed an evaluation system for China's PV industry policy, classifying and quantifying 307 photovoltaic industry policies issued from 1994 to 2016. The policies were investigated from four dimensions: policy measures, policy types, policy strength, and policy issuing departments. Based on this evaluation framework, the historical evolution and realistic effect of the policies were examined. The research supports the following conclusions.

From an evolution perspective, China's PV industry policy is broadly divided into three stages. Currently, grid support, operations specification and operation supervision are the main policy measures and low-level notifications are the main type of policy. The issued strength of policies is generally low. The enforcement strength of regional policy presents descending trend from the northern to the southern provinces and the similar trend from coastal provinces to inland provinces. The main policy issuing departments are the SC, the NDRC, and the NEA.

Regarding the effect of policy, of the 14 policy measures examined, only ten have positive correlations. The other policy measures are not yet mature and have no positive correlation. The policy for grid support, operations specification, and technical specification has significant positive correlation with the PV industry. All the policy departments have a positive correlation with the development of the PV industry. The most effective policy types are the sector-specific notices and announcements, and the best policy-issuing department is the NEA. In contrast, the issued effect of policies from the NDRC is not satisfactory. The issued strength of policy for grid support, operation specification, and 
operation supervision has a positive correlation with the development of the industry, but has not achieved the desired effect.

\subsection{Policy Implications}

According to the research results, the following aspects of PV industry policy should be improved.

(1) Cohesion between sectoral policies should be improved, the linkage of policies strengthened, policy-making among different departments coordinated, and complementarity of policies among different departments and levels increased. Meanwhile, the implementation of PV industry policy should have specific expectations. The authority should carry out systematic and prospective planning for the development of the PV industry from the perspective of a national strategy, then formulate feasible PV industry policies, and be effective in policy implementation and supervision.

(2) Grid support, operation specification, and operation supervision policies should be further improved. First, photovoltaic grid support should be promoted, solving the difficulties in the photovoltaic grid-connected system, and accelerating the pace with which the photovoltaic power network is developed. According to the proximity consumption principle, the implementation of renewable energy power generation should adhere to the requirements of full indemnificatory acquisition, complete PV power consumption work well, and prioritize the indemnificatory acquisition of power. Learning from foreign experiences, a mandatory market share system should be established and legislation, such as the Feed-in Tariff Law, should be enacted to ensure the utilization of renewable energy and implementation of PV power full indemnificatory acquisition. In addition, families and enterprises should be encouraged to invest in the PV power generation industry, promoting the diversified development of distributed PV applications, improving the tariff acquisition subsidy mechanism, and increasing people's positivity for investment in PV power generation. Second, the development of a standards and specification system should be accelerated, establishing a complete standards system for the PV industry, including public service platforms for testing and certification, as well as empirical research bases for PV applications. Meanwhile, attention must be paid to the internal specification, supervision and management of the PV industry so as to prevent the related policies from becoming a formality.

(3) The amendment-of-subsidy mechanism should be strengthened. At present, China's funding of renewable energy has a large gap, and the subsidies for PV power stations are seriously in arrears. The Chinese government should expand the sources of special subsidy funds for renewable energy, develop an innovative subsidy mechanism for PV power generation, and establish a green certificate trading mechanism. Meanwhile, to enhance the competitiveness of the PV industry, policies for scientific research (such as increasing deductions for research and development expenditure and establishing research and development funds) should be formulated to support key technology research of the PV industry.

(4) China's financial support, information support and personnel training policy measures are not mature; the formulation and implementation of financial and information support policies should be accelerated. The PV industry generally faces a financing problem, and it is difficult for the traditional financial support model to solve the financing needs of PV industry. The industry and government need to develop an innovative financing mode to break through the financing bottleneck. In addition, the Chinese government has too few information support policies. To reduce and avoid information asymmetry in the development of the PV industry, the government must strengthen information support and establish an information-sharing mechanism to help enterprises obtain the latest information and promote the healthy development of the PV industry. In addition, the government needs to strengthen the formulation of personnel training policies on the basis of talent introduction, supporting the training of high-level professional technology and management personnel and setting up relevant research teams.

(5) The global competitive advantages of China's PV industry should be accelerated. To cope with challenging international trade policies such as the anti-dumping and countervailing duties 
imposed in Europe and the USA, the Chinese government needs to increase the demand for the domestic PV market and promote the merger, reorganization and resource integration of the PV industry. The government also needs to conscientiously implement the national 'The Belt and Road' strategy and actively explore overseas emerging markets in South America, South Africa, and other countries, thereby promoting the diversification of China's PV market and enhancing the global competitive advantage of China's PV industry. At the same time, China's PV enterprises should be guided in investing overseas, actively promoting overseas mergers and acquisitions, and encouraging the establishment of PV manufacturing industry parks and capacity demonstration bases in the major PV markets, thus achieving industrial agglomeration and resource integration.

Acknowledgments: This study was supported by the Fundamental Research Funds for the Central Universities (2017XKZD12).

Author Contributions: Ruyin Long came up with the original idea and model for this article; and Wenhua Cui and Qianwen Li designed the model, calculated the data, and wrote the paper. All authors read and approved this version.

Conflicts of Interest: The authors declare that they have no conflict of interest.

\section{Appendix A}

Table A1. Classification of policy strength for China's photovoltaic (PV) industry policies.

\begin{tabular}{|c|c|}
\hline Value & Strength Description of 'Guidance Measures' \\
\hline & Government incentive \\
\hline 5 & Formulate issue-specific preferential policies for the development of the solar PV industry. \\
\hline 4 & Take coercive measures such as market share policy to develop the PV industry. \\
\hline 3 & Take the PV industry as a new economic growth point, and have corresponding incentive measures. \\
\hline 2 & Encourage the development of the solar PV industry. \\
\hline \multirow[t]{2}{*}{1} & Mention the development of solar power or the PV industry. \\
\hline & Green development \\
\hline 5 & $\begin{array}{l}\text { Implement the 'Renewable Energy Law' conscientiously and formulate relevant supporting policies and } \\
\text { regulations; Photovoltaic enterprises and projects should comply with laws and regulations such as } \\
\text { environmental conservation, energy-saving management; Photovoltaic manufacturing and power generation } \\
\text { projects implement the environmental impact assessment system. }\end{array}$ \\
\hline 4 & $\begin{array}{l}\text { Take green development as a national sustainable development strategy in the photovoltaic industry-related } \\
\text { policies; encourage taking the use of solar energy into energy-development, energy-saving and } \\
\text { emission-reduction planning. }\end{array}$ \\
\hline 3 & $\begin{array}{l}\text { Promote green development in policy, pay attention to the environmental benefits of solar energy utilization, } \\
\text { and encourage (through policy) projects to acquire the relevant green testing certification during construction. }\end{array}$ \\
\hline 2 & $\begin{array}{l}\text { Pay attention to environmental problems in the construction process of photovoltaic manufacturing and } \\
\text { power generation projects. }\end{array}$ \\
\hline 1 & Mention green development in policy. \\
\hline \multirow[t]{2}{*}{ Value } & Strength description of 'supporting measures' \\
\hline & Financial support \\
\hline 5 & Satisfy two or more of the following financial value items: $2,3,4$ \\
\hline 4 & $\begin{array}{l}\text { The policy stipulates that financial institutions provide low interest loans and preferential loans to PV } \\
\text { equipment manufacturers, PV power stations or PV power generation projects. }\end{array}$ \\
\hline 3 & Government or social capital provides guaranteed loans to the PV industry. \\
\hline 2 & $\begin{array}{l}\text { For PV enterprises, PV power plants or PV projects broaden financing channels and develop innovative } \\
\text { financial services such as stocks, bonds, funds and private investments. }\end{array}$ \\
\hline 1 & Mention support for development of the PV industry using financial measures. \\
\hline
\end{tabular}


Table A1. Cont.

\begin{tabular}{|c|c|}
\hline \multicolumn{2}{|r|}{ Technical support } \\
\hline 5 & Satisfy two or more of the following technical value items: $2,3,4$. \\
\hline 4 & $\begin{array}{l}\text { Support PV enterprises to carry out technological innovation and build research and development platforms } \\
\text { of PV power generation technology; research the key PV technology; encourage cooperative research and } \\
\text { production. }\end{array}$ \\
\hline 3 & $\begin{array}{l}\text { The research and development of PV technology is included in the special projects of technological } \\
\text { development. }\end{array}$ \\
\hline 2 & $\begin{array}{l}\text { Selectively introduce technologies of the PV industry; digestion, absorption and recreation of foreign } \\
\text { advanced technologies; promote technical exchanges; encourage enterprises to strengthen international } \\
\text { research and development cooperation. }\end{array}$ \\
\hline 1 & Mention the research and development of the photovoltaic technology. \\
\hline \multicolumn{2}{|r|}{ Personnel training } \\
\hline 5 & Satisfy two or more of the following personnel value items: $2,3,4$. \\
\hline 4 & $\begin{array}{l}\text { Train professional technology and management personnel by colleges and research institutes; support } \\
\text { universities, research institutions and enterprises to establish an international talent introduction and training } \\
\text { mechanism. }\end{array}$ \\
\hline 3 & $\begin{array}{l}\text { Integrate renewable energy knowledge and technology into education, set up related courses in higher or } \\
\text { polytechnic schools. }\end{array}$ \\
\hline 2 & $\begin{array}{l}\text { Explore the establishment of a personnel training system, standardize the training of photovoltaic } \\
\text { practitioners. }\end{array}$ \\
\hline 1 & Mention photovoltaic related personnel training. \\
\hline \multicolumn{2}{|r|}{ Grid support } \\
\hline 5 & Satisfy two or more of the following grid value items: $2,3,4$. \\
\hline 4 & $\begin{array}{l}\text { Acquire the full grid-connected power of renewable energy generation projects within the coverage of power } \\
\text { grid enterprises. }\end{array}$ \\
\hline 3 & $\begin{array}{l}\text { Set up the subregional benchmark feed-in tariff at PV power stations and establish a subsidy standard for } \\
\text { photovoltaic power generation, and a subsidy for PV price, to assure the difference between the average cost } \\
\text { of conventional energy and the value added in the sale price is shared by the whole society. }\end{array}$ \\
\hline 2 & $\begin{array}{l}\text { Formulate a supporting power grid construction plan, coordinate and promote the construction and } \\
\text { transformation of supporting grid; Strengthen the grid access and grid connected service of photovoltaic } \\
\text { power generation projects. }\end{array}$ \\
\hline 1 & Mention solving the photovoltaic power grid problems. \\
\hline \multicolumn{2}{|r|}{ Information support } \\
\hline 5 & Satisfy two or more of the following information value items: $2,3,4$. \\
\hline 4 & Evaluation of solar energy resources and pre-feasibility study of photovoltaic power plant projects \\
\hline 3 & The survey and publishing of solar energy information resources. \\
\hline 2 & Photovoltaic medium- and long-term development planning. \\
\hline 1 & Develop renewable energy industry development guidance catalogue. \\
\hline \multicolumn{2}{|r|}{ Project support } \\
\hline 5 & Satisfy two or more of the following project value items: $2,3,4$. \\
\hline 4 & Put forward the construction plan and organize the implementation of a photovoltaic demonstration project. \\
\hline 3 & $\begin{array}{l}\text { Implement quota subsidy policy of unit electricity for photovoltaic power generation projects in the } \\
\text { demonstration area. }\end{array}$ \\
\hline 2 & $\begin{array}{l}\text { Encourage the provinces (district, city) to use financial funds to support the construction of photovoltaic } \\
\text { demonstration projects. }\end{array}$ \\
\hline 1 & Mention the construction of photovoltaic demonstration projects. \\
\hline Value & Strength description of 'specification measures' \\
\hline \multicolumn{2}{|r|}{ Operation specification } \\
\hline 5 & Satisfy two or more of the following operation value items: $2,3,4$. \\
\hline 4 & $\begin{array}{l}\text { Inspect and evaluate work of important processes such as the construction operation, equipment operation } \\
\text { and parallel operation of photovoltaic power generation projects. }\end{array}$ \\
\hline 3 & Record the generating capacity, operational aspect and price of photovoltaic power generation projects. \\
\hline 2 & Macro guidance for the operation of photovoltaic power generation project. \\
\hline 1 & Mention the establishment of operation specifications for photovoltaic power generation projects. \\
\hline
\end{tabular}


Table A1. Cont.

\begin{tabular}{|c|c|}
\hline \multicolumn{2}{|r|}{ Technical specification } \\
\hline 5 & Satisfy two or more of the following technical value items: $2,3,4$. \\
\hline 4 & $\begin{array}{l}\text { Photovoltaic power plant projects need to comply with the technical standard of grid access of photovoltaic } \\
\text { power stations; Photovoltaic devices and products must be evaluated by the national inspection and } \\
\text { certification institution. }\end{array}$ \\
\hline 3 & The construction of photovoltaic standards system and the improvement of the industry standards system. \\
\hline 2 & The related technical standards of the PV industry. \\
\hline 1 & Mention the establishment of relevant technical standards for PV equipment or PV power stations. \\
\hline \multicolumn{2}{|r|}{$\begin{array}{l}\text { Product specification } \\
\end{array}$} \\
\hline 5 & Satisfy two or more of the following product value items: $2,3,4$ \\
\hline 4 & The access conditions for the PV product market and the specification of the PV manufacturing industry. \\
\hline 3 & Information disclosure of the PV products market, and limits on the capacity of PV manufacturing projects. \\
\hline 2 & Quality specifications, and improve product quality. \\
\hline 1 & Mention the specification of PV product quality and the PV product manufacturing market. \\
\hline Value & Strength description of 'supervision measures' \\
\hline \multicolumn{2}{|r|}{ Quality supervision } \\
\hline 5 & Satisfy two or more of the following quality value items: $2,3,4$. \\
\hline 4 & $\begin{array}{l}\text { Set up relevant departments and committees for solar PV products to carry out product quality supervision } \\
\text { and inspections of businesses. }\end{array}$ \\
\hline 3 & $\begin{array}{l}\text { Regularly organize relevant departments to carry out technological quality inspection of PV market products, } \\
\text { and focus on examining key technological functions and product quality of PV products. }\end{array}$ \\
\hline 2 & $\begin{array}{l}\text { Establish an excellent quality supervision system and an effective quality supervision mechanism, strengthen } \\
\text { the quality supervision and management of PV project construction. }\end{array}$ \\
\hline 1 & Mention the quality supervision of PV market products. \\
\hline \multicolumn{2}{|r|}{$\begin{array}{ll}\text { Operation supervision } \\
\end{array}$} \\
\hline 5 & Satisfy two or more of the following operation value items: $2,3,4$. \\
\hline 4 & $\begin{array}{l}\text { Establish a renewable energy project information system, and monitor the construction and operation of PV } \\
\text { power plant projects in various regions; establish an industrial monitoring and evaluation system. }\end{array}$ \\
\hline 3 & $\begin{array}{l}\text { Supervise and research the consumptive situation of the grid access, abandoned power, and electricity } \\
\text { subsidy settlements. }\end{array}$ \\
\hline 2 & $\begin{array}{l}\text { Implement information sharing of PV power generation project management and supervision, and } \\
\text { strengthen the operation supervision of PV power generation. }\end{array}$ \\
\hline 1 & Mention the operation supervision of PV power generation. \\
\hline
\end{tabular}

\section{Appendix B}

Table A2. The sorting of policy text.

\begin{tabular}{|c|c|c|c|c|c|}
\hline Num & Time & Policy Name & Policy Measure & Policy Department & Policy Type \\
\hline 1 & 1994.09 .19 & $\begin{array}{l}\text { Notice on Issuing the Science and } \\
\text { technology development } \\
\text { planning of power industry }\end{array}$ & $\begin{array}{l}\text { Guidance measures-GI } \\
\text { Supporting measures-TS }\end{array}$ & MOPI & Measures \\
\hline 2 & 1995.01.05 & $\begin{array}{l}\text { Notice on Issuing the outline for } \\
\text { the development of new energy } \\
\text { and renewable energy }\end{array}$ & $\begin{array}{c}\text { Guidance measures-GI } \\
\text { Supporting measures-IS, FIS, } \\
\text { FS, TS }\end{array}$ & NDRC, SSTC, SETC & Measures \\
\hline 3 & 1995.12 .28 & $\begin{array}{l}\text { Electric Power Law of the } \\
\text { People's Republic of China }\end{array}$ & Guidance measures-GI & NPC & Laws \\
\hline 4 & 1997.05.27 & $\begin{array}{l}\text { Interim Provisions on the } \\
\text { management of new energy } \\
\text { infrastructure projects }\end{array}$ & $\begin{array}{c}\text { Guidance measures-GI } \\
\text { Supporting measures-IS, TS }\end{array}$ & SPC & Measures \\
\hline 5 & 1999.01.12 & $\begin{array}{l}\text { Notice on further supporting } \\
\text { relevant issues on renewable } \\
\text { energy development }\end{array}$ & $\begin{array}{c}\text { Guidance measures-GI } \\
\text { Supporting measures-FS, FIS, } \\
\text { GS }\end{array}$ & NDRC, MOST & Notices \\
\hline 6 & 2001.10 .10 & $\begin{array}{l}\text { Notice on issuing the '10th } \\
\text { Five-Year Plan' for the } \\
\text { development of new energy and } \\
\text { renewable energy industries }\end{array}$ & $\begin{array}{c}\text { Guidance measures-GI } \\
\text { Supporting measures-IS, FIS, } \\
\text { TS } \\
\text { Specification measures-PSP, } \\
\text { TSP }\end{array}$ & SETC & Measures \\
\hline
\end{tabular}


Table A2. Cont.

\begin{tabular}{|c|c|c|c|c|c|}
\hline Num & Time & Policy Name & Policy Measure & Policy Department & Policy Type \\
\hline 7 & 2005.02 .28 & $\begin{array}{l}\text { Renewable Energy Law of the } \\
\text { People's Republic of China }\end{array}$ & $\begin{array}{c}\text { Guidance measures-GI, GD } \\
\text { Supporting measures-IS, TS, } \\
\text { PT, GS, FIS, FS } \\
\text { Supervision measures-OSU }\end{array}$ & NPC & Laws \\
\hline 8 & 2005.03.16 & $\begin{array}{l}\text { Notice on organizing the } \\
\text { implementation of } \\
\text { industrialization projects for the } \\
\text { renewable energy and new energy } \\
\text { high-tech industry }\end{array}$ & Supporting measures-TS & NDRC & Notices \\
\hline 9 & 2005.05 .01 & $\begin{array}{l}\text { Interim Measures for the } \\
\text { administration of Grid Power } \\
\text { Price }\end{array}$ & Supporting measures-GS & NDRC & Measures \\
\hline 10 & 2005.11 .10 & $\begin{array}{l}\text { Regulations on the administration } \\
\text { of energy efficiency in civil } \\
\text { buildings }\end{array}$ & $\begin{array}{l}\text { Guidance measures-GI } \\
\text { Supporting measures-TS }\end{array}$ & MOC & $\begin{array}{l}\text { Opinions and } \\
\text { Rules }\end{array}$ \\
\hline 11 & 2005.11 .29 & $\begin{array}{l}\text { Circular of the National } \\
\text { Development and Reform } \\
\text { Commission on Printing and } \\
\text { Distributing Catalog for the } \\
\text { Guidance of the Industrial } \\
\text { Development of Renewable } \\
\text { Energy }\end{array}$ & Supporting measures-IS & NDRC & Notices \\
\hline 12 & 2005.12 .26 & $\begin{array}{l}\text { Notice on Issuing the Outline for } \\
\text { the long-term Development of } \\
\text { science and technology } \\
(2006-2020)\end{array}$ & Guidance measures-GI & SC & $\begin{array}{l}\text { Opinions and } \\
\text { Rules }\end{array}$ \\
\hline 13 & 2006.01 .04 & $\begin{array}{l}\text { Notice of the National } \\
\text { Development and Reform } \\
\text { Commission on Issuing the Trial } \\
\text { Measures for the Management of } \\
\text { Prices and Allocation of Costs for } \\
\text { Electricity Generated from } \\
\text { Renewable Energy }\end{array}$ & $\begin{array}{l}\text { Guidance measures-GI } \\
\text { Supporting measures-GS }\end{array}$ & NDRC & Measures \\
\hline 14 & 2006.01 .05 & $\begin{array}{l}\text { Notice of the National } \\
\text { Development and Reform } \\
\text { Commission on Issuing } \\
\text { Administrative Provisions on } \\
\text { Renewable Energy Power } \\
\text { Generation }\end{array}$ & Supporting measures-GS & NDRC & $\begin{array}{l}\text { Opinions and } \\
\text { Rules }\end{array}$ \\
\hline 15 & 2006.05 .11 & $\begin{array}{l}\text { Notice on submitting the } \\
\text { Application and Demonstration of } \\
\text { Renewable Energy in Buildings }\end{array}$ & Supporting measures-IS & MOF, MOC & Notices \\
\hline 16 & 2006.05 .30 & $\begin{array}{l}\text { Notice on Issuing the Interim } \\
\text { Measures for the Administration } \\
\text { of Special Funds for the } \\
\text { Development of Renewable } \\
\text { Energy }\end{array}$ & $\begin{array}{l}\text { Guidance measures-GI } \\
\text { Supporting measures-FIS }\end{array}$ & $\mathrm{MOF}$ & Measures \\
\hline 17 & 2006.06 .26 & $\begin{array}{l}\text { Notice on further doing well the } \\
\text { feasibility study report for the } \\
\text { Application and Demonstration } \\
\text { projects of Renewable Energy in } \\
\text { Buildings }\end{array}$ & Supporting measures-IS & MOC & Notices \\
\hline 18 & 2006.08 .25 & $\begin{array}{l}\text { Implementation Opinions on } \\
\text { Accelerating the application of } \\
\text { renewable energy in buildings }\end{array}$ & $\begin{array}{c}\text { Guidance measures-GI,GD } \\
\text { Supporting } \\
\text { measures-TS,PS,FIS } \\
\text { Specification measures-TSP } \\
\text { Supervision measures-OSU }\end{array}$ & MOC, MOF & Measures \\
\hline 19 & 2006.09 .04 & $\begin{array}{l}\text { Interim Measures for the } \\
\text { administration of special funds } \\
\text { for the applications of renewable } \\
\text { energy in buildings }\end{array}$ & $\begin{array}{l}\text { Guidance measures-GI } \\
\text { Supporting measures-FIS }\end{array}$ & MOF, MOC & Measures \\
\hline 20 & 2007.01.11 & $\begin{array}{l}\text { Notice of the National } \\
\text { Development and Reform } \\
\text { Commission on Issuance of the } \\
\text { Interim Measures for Allocation } \\
\text { of Income from Surcharges on } \\
\text { Renewable Energy Power Prices }\end{array}$ & $\begin{array}{l}\text { Guidance measures-GI } \\
\text { Supporting measures-FIS }\end{array}$ & NDRC & Measures \\
\hline 21 & 2007.02 .13 & $\begin{array}{l}\text { Notice on strengthening the } \\
\text { administration of the Application } \\
\text { and Demonstration of Renewable } \\
\text { Energy in Buildings }\end{array}$ & Supervision measures-OSU & MOF, MOC & Notices \\
\hline
\end{tabular}


Table A2. Cont.

\begin{tabular}{|c|c|c|c|c|c|}
\hline Num & Time & Policy Name & Policy Measure & Policy Department & Policy Type \\
\hline 22 & 2007.04 .06 & $\begin{array}{l}\text { Notice on organizing the } \\
\text { implementation of major } \\
\text { industrialization projects for high } \\
\text { purity silicon material and } \\
\text { high-tech industry }\end{array}$ & Supporting measures-TS & NDRC & Notices \\
\hline 23 & 2007.04 .28 & $\begin{array}{l}\text { Notice on Issuing the '11th } \\
\text { Five-Year plan' for the } \\
\text { development of high technology } \\
\text { industry }\end{array}$ & $\begin{array}{c}\text { Guidance measures-GI } \\
\text { Supporting measures-FS, FIS, } \\
\text { PT } \\
\text { Specification measures-TSP }\end{array}$ & NDRC & Measures \\
\hline 24 & 2007.05 .23 & $\begin{array}{l}\text { Notice on Issuing a } \\
\text { comprehensive work plan for } \\
\text { energy-conservation and } \\
\text { emission-reduction }\end{array}$ & Guidance measures-GI & SC & Notices \\
\hline 25 & 2007.06.09 & $\begin{array}{l}\text { Notice on Issuing the "11th } \\
\text { Five-Year Plan" for the rural } \\
\text { economic and social development }\end{array}$ & Guidance measures-GI & NDRC & Measures \\
\hline 26 & 2007.07.25 & $\begin{array}{l}\text { Regulatory Measures for Grid } \\
\text { Enterprises' Full Purchase of } \\
\text { Renewable Energy Electricity }\end{array}$ & $\begin{array}{l}\text { Supporting measures-GS } \\
\text { Supervision measures-OSU }\end{array}$ & SERC & Measures \\
\hline 27 & 2007.08.31 & $\begin{array}{l}\text { Notice on Issuing the medium } \\
\text { and long term development plan } \\
\text { for renewable energy }\end{array}$ & $\begin{array}{l}\text { Guidance measures-GI,GD } \\
\text { Supporting measures-IS, GS, } \\
\text { PS, FIS, TS }\end{array}$ & NDRC & Measures \\
\hline 28 & 2007.10 .28 & $\begin{array}{l}\text { Economizing Energy Law of the } \\
\text { People's Republic of China ( } 2007 \\
\text { Amendment) }\end{array}$ & Guidance measures-GI & NPC & Laws \\
\hline 29 & 2007.10 .31 & $\begin{array}{l}\text { Notice on the issuing the Guiding } \\
\text { Catalogue for foreign } \\
\text { investment(2007 Amendment) }\end{array}$ & $\begin{array}{l}\text { Guidance measures-GI } \\
\text { Supporting measures-FS }\end{array}$ & GAC & Notices \\
\hline 30 & 2008.03 .03 & $\begin{array}{l}\text { Notice on issuing the ' } 11 \text { th } \\
\text { Five-Year Plan' for the } \\
\text { development of renewable energy }\end{array}$ & $\begin{array}{c}\text { Guidance measures-GI,GD } \\
\text { Supporting measures-IS, GS, } \\
\text { TS, FIS } \\
\text { Specification measures-TSP } \\
\text { Supervision measures-QS }\end{array}$ & NDRC & Measures \\
\hline 31 & 2008.06 .02 & $\begin{array}{l}\text { Notice on organizing the } \\
\text { declaring of application } \\
\text { demonstration projects of } \\
\text { renewable energy in buildings in } \\
2008\end{array}$ & Supporting measures-PS & MOF, MOHURD & Notices \\
\hline 32 & 2008.06 .10 & $\begin{array}{l}\text { Notice on inspecting the Grid } \\
\text { Enterprises' Full Acquisition of } \\
\text { Renewable Energy Electricity and } \\
\text { the implementation of renewable } \\
\text { energy tariff policies }\end{array}$ & Supervision measures-OSU & SERC & Notices \\
\hline 33 & 2008.07.15 & $\begin{array}{l}\text { Notice on Issuing the work } \\
\text { arrangements for } \\
\text { energy-conservation and } \\
\text { emission-reduction in } 2008\end{array}$ & Guidance measures-GI & SC & Notices \\
\hline 34 & 2008.08 .01 & $\begin{array}{l}\text { Regulations on energy } \\
\text { conservation for civil buildings }\end{array}$ & Guidance measures-GI & SC & $\begin{array}{l}\text { Regulations } \\
\text { and Orders }\end{array}$ \\
\hline 35 & 2008.11.11 & $\begin{array}{l}\text { Notice on renewable energy price } \\
\text { subsidies and quota trading } \\
\text { schemes from October } 2007 \text { to } \\
\text { June } 2008\end{array}$ & $\begin{array}{c}\text { Guidance measures-GI } \\
\text { Supporting measures-FIS, GS }\end{array}$ & NDRC, SERC & Notices \\
\hline 36 & 2009.03 .23 & $\begin{array}{l}\text { Implementation Opinions on } \\
\text { accelerating the applications of } \\
\text { solar photovoltaic in buildings }\end{array}$ & $\begin{array}{c}\text { Guidance measures-GI } \\
\text { Supporting measures-PS, FIS } \\
\text { Specification measures-TSP }\end{array}$ & MOF, MOHURD & Measures \\
\hline 37 & 2009.03 .23 & $\begin{array}{l}\text { Interim Measures on the } \\
\text { administration of financial } \\
\text { subsidies for the application of } \\
\text { solar photovoltaic in buildings }\end{array}$ & $\begin{array}{c}\text { Guidance measures-GI } \\
\text { Supporting measures-FIS,GS }\end{array}$ & $\mathrm{MOF}$ & Measures \\
\hline 38 & 2009.03 .31 & $\begin{array}{l}\text { Notice on the authorization of the } \\
\text { national quality supervision and } \\
\text { Inspection Center for solar } \\
\text { photovoltaic products }\end{array}$ & Supervision measures-QS & $\mathrm{CNCA}$ & Notices \\
\hline 39 & 2009.07.16 & $\begin{array}{l}\text { Interim Measures on the } \\
\text { administration of government } \\
\text { subsidies of golden sun } \\
\text { demonstration project }\end{array}$ & $\begin{array}{l}\text { Supporting measures-FIS, GS } \\
\text { Specification measures-OS } \\
\text { Supervision measures-OSU }\end{array}$ & MOF, MOST, NEA & Measures \\
\hline
\end{tabular}


Table A2. Cont.

\begin{tabular}{|c|c|c|c|c|c|}
\hline Num & Time & Policy Name & Policy Measure & Policy Department & Policy Type \\
\hline 40 & 2009.07.19 & $\begin{array}{l}\text { Notice on issuing the work } \\
\text { arrangements for } \\
\text { energy-conservation and } \\
\text { emission-reduction in } 2009\end{array}$ & $\begin{array}{l}\text { Guidance measures-GI } \\
\text { Supporting measures-TS }\end{array}$ & SC & Notices \\
\hline 41 & 2009.07.22 & $\begin{array}{l}\text { Notice on the publication of the } \\
\text { catalogue of technologies and } \\
\text { products for import (2009) }\end{array}$ & Supporting measures-TS, FIS & $\begin{array}{l}\text { NDRC, MOF, } \\
\text { MOFCOM }\end{array}$ & Notices \\
\hline 42 & 2009.09 .26 & $\begin{array}{l}\text { Notice on retraining excess } \\
\text { capacity in some industries and } \\
\text { repeated construction and } \\
\text { guiding the healthy development } \\
\text { of the industry }\end{array}$ & $\begin{array}{l}\text { Guidance measures-GD } \\
\text { Specification measures-PSP }\end{array}$ & SC & $\begin{array}{l}\text { Opinions and } \\
\text { Rules }\end{array}$ \\
\hline 43 & 2009.12.07 & $\begin{array}{l}\text { Notice on the establishment of } \\
\text { standard propulsion group for } \\
\text { photovoltaic power generation } \\
\text { and industrialization }\end{array}$ & Specification measures-TSP & SAC & Notices \\
\hline 44 & 2009.12.11 & $\begin{array}{l}\text { Notice on the establishment of } \\
\text { national solar photovoltaic } \\
\text { products quality supervision and } \\
\text { inspection center }\end{array}$ & Supervision measures-QS & AQSIQ, CNCA & Notices \\
\hline 45 & 2009.12.26 & $\begin{array}{l}\text { Renewable Energy Law of the } \\
\text { People's Republic of China ( } 2009 \\
\text { Amendment) }\end{array}$ & $\begin{array}{c}\text { Guidance measures-GI, GD } \\
\text { Supporting measures-IS, TS, } \\
\text { PT, GS, FIS, FS } \\
\text { Supervision measures-OSU }\end{array}$ & NPC & Laws \\
\hline 46 & 2009.12.31 & $\begin{array}{l}\text { Notice on Issuing the catalogue of } \\
\text { preferential enterprise income tax } \\
\text { for environmental protection and } \\
\text { energy conservation and water } \\
\text { saving projects (for Trial } \\
\text { Implementation) }\end{array}$ & Supporting measures-FIS & MOF, NDRC, SAT & Notices \\
\hline 47 & 2010.04 .12 & $\begin{array}{l}\text { Notice on organizing the } \\
\text { declaring of application } \\
\text { demonstration projects of solar } \\
\text { photovoltaic in buildings in } 2010\end{array}$ & Supporting measures-PS & MOF, MOHURD & Notices \\
\hline 48 & 2010.05 .07 & $\begin{array}{l}\text { Opinions on encouraging and } \\
\text { guiding the healthy development } \\
\text { of private investment }\end{array}$ & $\begin{array}{l}\text { Guidance measures-GI } \\
\text { Supporting measures-FS }\end{array}$ & SC & $\begin{array}{l}\text { Opinions and } \\
\text { Rules }\end{array}$ \\
\hline 49 & 2010.08 .20 & $\begin{array}{l}\text { Notice on renewable energy price } \\
\text { subsidies and quotas trading } \\
\text { scheme from July to December in } \\
2009\end{array}$ & $\begin{array}{c}\text { Guidance measures-GI } \\
\text { Supporting measures-FIS, GS }\end{array}$ & NDRC, SERC & Notices \\
\hline 50 & 2010.09 .03 & $\begin{array}{l}\text { Notice on organizing the training } \\
\text { courses for new energy and } \\
\text { renewable energy technologies }\end{array}$ & Supporting measures-PT & MOHURD & Notices \\
\hline 51 & 2010.09 .21 & $\begin{array}{l}\text { Notice on strengthening the } \\
\text { construction management of the } \\
\text { golden sun demonstration project } \\
\text { and solar photovoltaic building } \\
\text { demonstration project }\end{array}$ & $\begin{array}{c}\text { Guidance measures-GI } \\
\text { Supporting measures-PS, FIS, } \\
\text { GS } \\
\text { Specification measures-TSP } \\
\text { Supervision measures-OSU }\end{array}$ & $\begin{array}{c}\text { MOF, MOST, } \\
\text { MOHURD, NEA }\end{array}$ & Notices \\
\hline 52 & 2010.10 .10 & $\begin{array}{l}\text { Decision on accelerating the } \\
\text { cultivation and development of } \\
\text { strategic emerging industries }\end{array}$ & $\begin{array}{l}\text { Guidance measures-GI } \\
\text { Supporting measures-GS }\end{array}$ & SC & $\begin{array}{l}\text { Opinions and } \\
\text { Rules }\end{array}$ \\
\hline 53 & 2010.12 .28 & $\begin{array}{l}\text { Notice on the authorization of the } \\
\text { national photovoltaic products } \\
\text { quality supervision and } \\
\text { Inspection Center in Chengdu }\end{array}$ & Supervision measures-QS & $\mathrm{CNCA}$ & Notices \\
\hline 54 & 2011.01.27 & $\begin{array}{l}\text { Notice on organizing the } \\
\text { implementation of integrated } \\
\text { demonstration of solar } \\
\text { photovoltaic building applications }\end{array}$ & $\begin{array}{c}\text { Guidance measures-GI } \\
\text { Supporting measures-FIS } \\
\text { Specification measures-TSP } \\
\text { Supervision measures-OSU }\end{array}$ & MOF, MOHURD & Notices \\
\hline 55 & 2011.07.24 & $\begin{array}{l}\text { Notice on improving the feed-in } \\
\text { tariff policy of solar photovoltaic } \\
\text { power generation }\end{array}$ & Supporting measures-GS & NDRC & Notices \\
\hline 56 & 2011.08.12 & $\begin{array}{l}\text { Notice on strengthening the } \\
\text { follow-up work management of } \\
\text { solar photovoltaic building } \\
\text { application demonstration }\end{array}$ & Supervision measures-OSU & MOF, MOHURD & Notices \\
\hline
\end{tabular}


Table A2. Cont.

\begin{tabular}{|c|c|c|c|c|c|}
\hline Num & Time & Policy Name & Policy Measure & Policy Department & Policy Type \\
\hline 57 & 2011.11.29 & $\begin{array}{l}\text { Notice of the General Office of the } \\
\text { Ministry of Finance and the } \\
\text { General Office of the Ministry of } \\
\text { Housing and Urban-Rural } \\
\text { Development on Organizing the } \\
\text { Work of demonstrations for } \\
\text { Application of Renewable Energy } \\
\text { in Buildings in } 2012\end{array}$ & Supporting measures-PS & MOF, MOHURD & Notices \\
\hline 58 & 2012.01.01 & $\begin{array}{l}\text { Notice of the Ministry of Finance, } \\
\text { the National Development and } \\
\text { Reform Commission and the } \\
\text { National Energy Administration } \\
\text { on Issuing the Interim Measures } \\
\text { for the Administration of the } \\
\text { Collection and Use of the } \\
\text { Renewable Energy Development } \\
\text { Fund }\end{array}$ & $\begin{array}{l}\text { Guidance measures-GI } \\
\text { Supporting measures-FIS }\end{array}$ & MOF, NDRC, NEA & Measures \\
\hline 59 & 2012.02 .13 & $\begin{array}{l}\text { Notice on organizing the } \\
\text { implementation of demonstration } \\
\text { projects of the state organs' } \\
\text { rooftop photovoltaic power } \\
\text { generation }\end{array}$ & Supporting measures-PS & GOASC & Notices \\
\hline 60 & 2012.03.14 & $\begin{array}{l}\text { Notice of the Ministry of Finance, } \\
\text { National Development and } \\
\text { Reform Commission, and } \\
\text { National Energy Administration } \\
\text { on Issuing the Interim } \\
\text { Administrative Measures for } \\
\text { Tariff Premium Subsidy Funds for } \\
\text { Renewable Energy }\end{array}$ & $\begin{array}{c}\text { Guidance measures-GI } \\
\text { Supporting measures-FIS, GS }\end{array}$ & MOF, NDRC, NEA & Measures \\
\hline 61 & 2012.03.27 & $\begin{array}{l}\text { Notice on Issuing the "12th } \\
\text { Five-Year Plan" special plan for } \\
\text { the development of solar power } \\
\text { generation technology }\end{array}$ & $\begin{array}{c}\text { Guidance measures-GI } \\
\text { Supporting measures-IS, TS, } \\
\text { PT, FIS, FS, PS } \\
\text { Specification measures-TSP }\end{array}$ & MOST & Measures \\
\hline 62 & 2012.07.07 & $\begin{array}{l}\text { Notice on Issuing the "12th } \\
\text { Five-Year Plan" for the } \\
\text { development of solar power } \\
\text { generation }\end{array}$ & $\begin{array}{c}\text { Guidance measures-GD } \\
\text { Supporting measures-PS, TS, } \\
\text { IS, GS } \\
\text { Specification measures-OS, } \\
\text { TSP, PSP } \\
\text { Supervision measures-OSU }\end{array}$ & NEA & Measures \\
\hline 63 & 2012.07.09 & $\begin{array}{l}\text { Notice on Issuing the "12th } \\
\text { Five-Year Plan" for the } \\
\text { development of national strategic } \\
\text { emerging industry }\end{array}$ & $\begin{array}{c}\text { Supporting measures-IS, TS, } \\
\text { PS }\end{array}$ & SC & $\begin{array}{l}\text { Opinions and } \\
\text { Rules }\end{array}$ \\
\hline 64 & 2012.09.14 & $\begin{array}{l}\text { Notice on declaring distributed } \\
\text { photovoltaic power generation } \\
\text { demonstration area }\end{array}$ & $\begin{array}{c}\text { Guidance measures-GI } \\
\text { Supporting measures-FIS, } \\
\text { GS, PS, TS }\end{array}$ & NEA & Notices \\
\hline 65 & 2012.11.20 & $\begin{array}{l}\text { Notice on Issuing the scheme of } \\
\text { quality supervision system for } \\
\text { renewable energy power } \\
\text { generation projects }\end{array}$ & Supervision measures-QS & NEA & Notices \\
\hline 66 & 2012.11.26 & $\begin{array}{l}\text { Notice on renewable energy price } \\
\text { subsidies and quota trading } \\
\text { schemes form October } 2010 \text { to } \\
\text { April } 2011\end{array}$ & $\begin{array}{c}\text { Guidance measures-GI } \\
\text { Supporting measures-FIS, GS }\end{array}$ & NDRC, SERC & Notices \\
\hline 67 & 2012.12 .12 & $\begin{array}{l}\text { Notice on the pre allocation of } \\
\text { additional subsidies for } \\
\text { renewable energy prices in } 2012\end{array}$ & $\begin{array}{l}\text { Guidance measures-GI } \\
\text { Supporting measures-FIS }\end{array}$ & $\mathrm{MOF}$ & Notices \\
\hline 68 & 2013.03.29 & $\begin{array}{l}\text { Notice on the Ministry of Finance } \\
\text { on Allocating Additional } \\
\text { Subsidies for Renewable Energy } \\
\text { Electricity Prices }\end{array}$ & $\begin{array}{l}\text { Guidance measures-GI } \\
\text { Supporting measures-FIS }\end{array}$ & MOF & Notices \\
\hline 69 & 2013.07.04 & $\begin{array}{l}\text { Opinions on promoting the } \\
\text { healthy development of } \\
\text { photovoltaic industry }\end{array}$ & $\begin{array}{c}\text { Guidance measures-GI } \\
\text { Supporting measures-GS, } \\
\text { FIS, FS, TS, PT } \\
\text { Specification measures-TSP } \\
\text { Supervision measures-OSU }\end{array}$ & SC & $\begin{array}{l}\text { Opinions and } \\
\text { Rules }\end{array}$ \\
\hline 70 & 2013.07.22 & $\begin{array}{l}\text { Notice on developing the } \\
\text { supervision research for the } \\
\text { consumption situation of wind } \\
\text { power and solar photovoltaic } \\
\text { power }\end{array}$ & Supervision measures-OSU & NEA & Notices \\
\hline
\end{tabular}


Table A2. Cont.

\begin{tabular}{|c|c|c|c|c|c|}
\hline Num & Time & Policy Name & Policy Measure & Policy Department & Policy Type \\
\hline 71 & 2013.07 .24 & $\begin{array}{l}\text { Notice on the issues of } \\
\text { implementing the subsidy policy } \\
\text { according to the amount of } \\
\text { electricity in the distributed } \\
\text { photovoltaic power generation }\end{array}$ & $\begin{array}{l}\text { Guidance measures-GI } \\
\text { Supporting measures-FIS }\end{array}$ & $\mathrm{MOF}$ & Notices \\
\hline 72 & 2013.08 .22 & $\begin{array}{l}\text { Opinions on supporting the } \\
\text { financial Services in distributed } \\
\text { Photovoltaic Generation }\end{array}$ & $\begin{array}{l}\text { Guidance measures-GI } \\
\text { Supporting measures-FS }\end{array}$ & NEA, CDB & Measures \\
\hline 73 & 2013.08 .26 & $\begin{array}{l}\text { Notice on promoting the healthy } \\
\text { development of PV industry by } \\
\text { using price leverage }\end{array}$ & $\begin{array}{c}\text { Guidance measures-GI } \\
\text { Supporting measures-GS, } \\
\text { FIS, GS } \\
\text { Specification measures-OS }\end{array}$ & NDRC & Notices \\
\hline 74 & 2013.08 .29 & $\begin{array}{l}\text { Interim Measures for the } \\
\text { administration of photovoltaic } \\
\text { power station projects }\end{array}$ & $\begin{array}{c}\text { Guidance measures-GI } \\
\text { Supporting measures-IS, GS, } \\
\text { FIS } \\
\text { Specification measures-TSP } \\
\text { Supervision } \\
\text { measures-QS,OSU }\end{array}$ & NEA & Measures \\
\hline 75 & 2013.09 .10 & $\begin{array}{l}\text { Notice of the Ministry of Finance } \\
\text { on Adjusting the Standards for } \\
\text { the Collection of Surcharges on } \\
\text { Renewable Energy Power Prices }\end{array}$ & $\begin{array}{l}\text { Guidance measures-GI } \\
\text { Supporting measures-FIS }\end{array}$ & $\mathrm{MOF}$ & Notices \\
\hline 76 & 2013.09 .23 & $\begin{array}{l}\text { Notice of the Ministry of Finance } \\
\text { and the State Administration of } \\
\text { Taxation on the Value-added Tax } \\
\text { Policy for Photovoltaic Power } \\
\text { Generation }\end{array}$ & $\begin{array}{l}\text { Guidance measures-GI } \\
\text { Supporting measures-FIS }\end{array}$ & MOF, SAT & Notices \\
\hline 77 & 2013.10 .11 & $\begin{array}{l}\text { Interim Measures for the } \\
\text { administration of the norms } \\
\text { announcement of the photovoltaic } \\
\text { manufacturing industry }\end{array}$ & $\begin{array}{c}\text { Guidance measures-GD } \\
\text { Specification measures-TSP, } \\
\text { PSP }\end{array}$ & MIIT & Measures \\
\hline 78 & 2013.11.18 & $\begin{array}{l}\text { Interim Measures for the } \\
\text { administration of distributed } \\
\text { generation projects }\end{array}$ & $\begin{array}{c}\text { Guidance measures-GI } \\
\text { Supporting measures-GS, FIS } \\
\text { Specification measures-TSP } \\
\text { Supervision measures-OSU }\end{array}$ & NEA & Measures \\
\hline 79 & 2013.11.19 & $\begin{array}{l}\text { Notice on the issues of the } \\
\text { exemption of government funds } \\
\text { for the spontaneous use of } \\
\text { distributed photovoltaic power } \\
\text { generation }\end{array}$ & $\begin{array}{l}\text { Guidance measures-GI } \\
\text { Supporting measures-FIS }\end{array}$ & $\mathrm{MOF}$ & Notices \\
\hline 80 & 2013.11.26 & $\begin{array}{l}\text { Notice of the National Energy } \\
\text { Administration on Issuing the } \\
\text { Interim Measures for the } \\
\text { Administration of Distributed } \\
\text { Power Generation }\end{array}$ & $\begin{array}{l}\text { Supporting measures-GS } \\
\text { Supervision measures-OSU }\end{array}$ & NEA & Measures \\
\hline 81 & 2014.01.17 & $\begin{array}{l}\text { Notice on Issuing the additional } \\
\text { construction scale of photovoltaic } \\
\text { power generation in } 2014\end{array}$ & $\begin{array}{l}\text { Supporting measures-TS, GS } \\
\text { Supervision measures-OSU }\end{array}$ & NEA & Notices \\
\hline 82 & 2014.02 .08 & $\begin{array}{l}\text { Implementation opinions on } \\
\text { strengthening the work of } \\
\text { product testing and certification }\end{array}$ & $\begin{array}{l}\text { Specification measures-TSP } \\
\text { Supervision measures-QS }\end{array}$ & CNCA, NEA & Measures \\
\hline 83 & 2014.02.19 & $\begin{array}{l}\text { Notice on organizing the } \\
\text { recommendation of key projects } \\
\text { in the photovoltaic industry in } \\
2014\end{array}$ & $\begin{array}{c}\text { Guidance measures-GI } \\
\text { Supporting measures-FS, TS, } \\
\text { PS }\end{array}$ & MIIT, CDB & Notices \\
\hline 84 & 2014.03.10 & $\begin{array}{l}\text { Notice on Issuing the work plan } \\
\text { for strengthening the information } \\
\text { monitoring of photovoltaic } \\
\text { industry }\end{array}$ & $\begin{array}{l}\text { Specification measures-OS } \\
\text { Supervision measures-OSU }\end{array}$ & NEA & Notices \\
\hline 85 & 2014.04 .21 & $\begin{array}{l}\text { Report on the work of energy } \\
\text { conservation and emission } \\
\text { reduction }\end{array}$ & $\begin{array}{l}\text { Guidance measures-GI } \\
\text { Supporting measures-GS }\end{array}$ & SC & Notices \\
\hline 86 & 2014.05 .04 & $\begin{array}{l}\text { Notice on the authorization of the } \\
\text { national quality supervision and } \\
\text { Inspection Center for solar } \\
\text { photovoltaic products in } \\
\text { Guangdong }\end{array}$ & Supervision measures-QS & $\mathrm{CNCA}$ & Notices \\
\hline
\end{tabular}


Table A2. Cont.

\begin{tabular}{|c|c|c|c|c|c|}
\hline Num & Time & Policy Name & Policy Measure & Policy Department & Policy Type \\
\hline 87 & 2014.05 .20 & $\begin{array}{l}\text { Notice on strengthening the } \\
\text { information statistics and } \\
\text { submission of photovoltaic power } \\
\text { generation projects }\end{array}$ & Supervision measures-OSU & NEA & Notices \\
\hline 88 & 2014.06 .07 & $\begin{array}{l}\text { Notice on Issuing the energy } \\
\text { development strategy action plan } \\
\text { from } 2014 \text { to } 2020\end{array}$ & $\begin{array}{c}\text { Guidance measures-GI } \\
\text { Supporting measures-IS, GS }\end{array}$ & SC & Notices \\
\hline 89 & 2014.07.01 & $\begin{array}{l}\text { Notice on Issuing grid scheduling } \\
\text { agreement model text of wind } \\
\text { and photovoltaic power station }\end{array}$ & Specification measures-OS & NEA, SAIC & Notices \\
\hline 90 & 2014.09.02 & $\begin{array}{l}\text { Notice of the National Energy } \\
\text { Administration on Further } \\
\text { Implementing Relevant Policies } \\
\text { on Distributed Photovoltaic } \\
\text { Power Generation }\end{array}$ & $\begin{array}{c}\text { Guidance measures-GI,GD } \\
\text { Supporting measures-IS, FIS, } \\
\text { FS, GS, PS } \\
\text { Specification measures-TSP } \\
\text { Supervision measures-OSU }\end{array}$ & NEA & Notices \\
\hline 91 & 2014.09 .10 & $\begin{array}{l}\text { Notice on the establishment of the } \\
\text { national solar photovoltaic } \\
\text { products quality supervision and } \\
\text { Inspection Center in Guangdong }\end{array}$ & Supervision measures-QS & AQSIQ, CNCA & Notices \\
\hline 92 & 2014.10 .09 & $\begin{array}{l}\text { Notice on Further Strengthening } \\
\text { the Construction and Operation } \\
\text { Management for Photovoltaic } \\
\text { Power Stations }\end{array}$ & $\begin{array}{c}\text { Guidance measures-GI,GD } \\
\text { Supporting measures-PS, GS, } \\
\text { FS } \\
\text { Specification measures-TSP } \\
\text { Supervision measures-OSU }\end{array}$ & NEA & Notices \\
\hline 93 & 2014.10 .11 & $\begin{array}{l}\text { Notice on the implementation of } \\
\text { the work plan for the photovoltaic } \\
\text { poverty alleviation projects }\end{array}$ & $\begin{array}{l}\text { Guidance measures-GI } \\
\text { Supporting measures-FIS }\end{array}$ & NEA, SC & Notices \\
\hline 94 & 2014.10.15 & $\begin{array}{l}\text { Notice on increasing the } \\
\text { construction scale of power } \\
\text { generation in Xinjiang } \\
\text { autonomous region and Xinjiang } \\
\text { production and Construction } \\
\text { Corps in } 2014\end{array}$ & Supporting measures-GS & NEA & Notices \\
\hline 95 & 2014.10 .28 & $\begin{array}{l}\text { Notice on regulating the order of } \\
\text { investment and development of } \\
\text { photovoltaic power station }\end{array}$ & $\begin{array}{l}\text { Guidance measures-GD } \\
\text { Supporting measures-IS } \\
\text { Specification measures-OS } \\
\text { Supervision measures-OSU }\end{array}$ & NEA & Notices \\
\hline 96 & 2014.11.21 & $\begin{array}{l}\text { Notice on promoting the } \\
\text { construction of distributed PV } \\
\text { application demonstration area }\end{array}$ & $\begin{array}{c}\text { Guidance measures-GI } \\
\text { Supporting measures-FS, GS, } \\
\text { PS, IS } \\
\text { Specification } \\
\text { measures-TSP,OS } \\
\text { Supervision measures-OSU }\end{array}$ & NEA & Notices \\
\hline 97 & 2014.12 .16 & $\begin{array}{l}\text { Notice on do a good job of } \\
\text { connecting the network of } \\
\text { Photovoltaic power generation } \\
\text { projects in } 2014\end{array}$ & $\begin{array}{l}\text { Supporting measures-GS } \\
\text { Supervision measures-OSU }\end{array}$ & NEA & Notices \\
\hline 98 & 2014.12.16 & $\begin{array}{l}\text { Notice on doing well the } \\
\text { preparation work of ' } 13 \text { th } \\
\text { Five-Year Plan' for the solar } \\
\text { energy development }\end{array}$ & $\begin{array}{l}\text { Guidance measures-GD } \\
\text { Supporting measures-PS, IS }\end{array}$ & NEA & Notices \\
\hline 99 & 2014.12 .30 & $\begin{array}{l}\text { Opinions of the Ministry of } \\
\text { Industry and Information } \\
\text { Technology on Further } \\
\text { Optimizing the Market } \\
\text { Environment for the Merger and } \\
\text { Restructuring of Photovoltaic } \\
\text { Enterprises }\end{array}$ & $\begin{array}{c}\text { Guidance measures-GI } \\
\text { Supporting measures-TS, FIS, } \\
\text { FS } \\
\text { Specification measures-PSP }\end{array}$ & MIIT & Measures \\
\hline 100 & 2015.01.09 & $\begin{array}{l}\text { Notice on the establishment of } \\
\text { photovoltaic product testing and } \\
\text { certification technical committee }\end{array}$ & Specification measures-TSP & CNCA,NEA & Notices \\
\hline 101 & 2015.03 .15 & $\begin{array}{l}\text { Opinions on further deepening } \\
\text { the reform of electric power } \\
\text { system }\end{array}$ & $\begin{array}{l}\text { Supporting measures-GS } \\
\text { Specification measures-TSP }\end{array}$ & SC & $\begin{array}{l}\text { Opinions and } \\
\text { Rules }\end{array}$ \\
\hline 102 & 2015.03.16 & $\begin{array}{l}\text { Notice on Issuing the } 2015 \\
\text { implementation plan for the } \\
\text { construction of photovoltaic } \\
\text { power generation }\end{array}$ & $\begin{array}{l}\text { Guidance measures-GI } \\
\text { Supporting measures-FIS, GS } \\
\text { Supervision measures-OSU }\end{array}$ & NEA & Notices \\
\hline
\end{tabular}


Table A2. Cont.

\begin{tabular}{|c|c|c|c|c|c|}
\hline Num & Time & Policy Name & Policy Measure & Policy Department & Policy Type \\
\hline 103 & 2015.03 .20 & $\begin{array}{l}\text { Guiding opinions on improving } \\
\text { the operation of electric power } \\
\text { and promoting the development } \\
\text { of clean energy }\end{array}$ & $\begin{array}{l}\text { Supporting measures-GS } \\
\text { Supervision measures-OSU }\end{array}$ & NDRC, NEA & Measures \\
\hline 104 & 2015.03 .31 & $\begin{array}{l}\text { Notice on carrying out the } \\
\text { declaration of the norms of the } \\
\text { photovoltaic manufacturing } \\
\text { industry }\end{array}$ & Specification measures-PSP & MIIT & Notices \\
\hline 105 & 2015.04 .02 & $\begin{array}{l}\text { Notice on Issuing the Interim } \\
\text { Measures for the Administration } \\
\text { of Special Funds for the } \\
\text { Development of Renewable } \\
\text { Energy }\end{array}$ & $\begin{array}{l}\text { Guidance measures-GI } \\
\text { Supporting measures-FIS }\end{array}$ & $\mathrm{MOF}$ & Measures \\
\hline 106 & 2015.04 .07 & $\begin{array}{l}\text { Notice on carrying out the quality } \\
\text { inspection for the national } \\
\text { photovoltaic power generation } \\
\text { project }\end{array}$ & $\begin{array}{c}\text { Specification measures-TSP, } \\
\text { OS }\end{array}$ & NEA & Notices \\
\hline 107 & 2015.04 .13 & $\begin{array}{l}\text { Guiding opinions on further } \\
\text { improving the "13th Five-Year" } \\
\text { planning work for the } \\
\text { development of renewable energy }\end{array}$ & Supporting measures-IS & NEA & Measures \\
\hline 108 & 2015.04 .20 & $\begin{array}{l}\text { Notice on Issuing the } \\
\text { standardization creation } \\
\text { specification of safety production } \\
\text { of photovoltaic enterprises }\end{array}$ & Specification measures-OS & NEA, SAWS & Notices \\
\hline 109 & 2015.06 .01 & $\begin{array}{l}\text { Opinions on promoting the } \\
\text { application of advanced } \\
\text { photovoltaic technology products } \\
\text { and industrial upgrading }\end{array}$ & $\begin{array}{c}\text { Guidance measures-GI } \\
\text { Supporting measures-FIS, TS } \\
\text { Specification measures-PSP, } \\
\text { TSP } \\
\text { Supervision measures-QS, } \\
\text { OSU }\end{array}$ & NEA,MIIT,CNCA & Measures \\
\hline 110 & 2015.09 .06 & $\begin{array}{l}\text { Notice on the establishment of the } \\
\text { International Electro-technical } \\
\text { Commission's mutual recognition } \\
\text { system for renewable energy } \\
\text { equipment certification }\end{array}$ & Specification measures-TSP & $\mathrm{CNCA}$ & Notices \\
\hline 111 & 2015.09 .08 & $\begin{array}{l}\text { Notice on Issuing the statutes of } \\
\text { photovoltaic products inspection } \\
\text { and certification technical } \\
\text { committee }\end{array}$ & Specification measures-TSP & $\mathrm{CNCA}$ & Notices \\
\hline 112 & 2015.09 .24 & $\begin{array}{l}\text { Notice on increasing the } \\
\text { construction scale of photovoltaic } \\
\text { power stations in some areas in } \\
2015\end{array}$ & Supporting measures-GS & NEA & Notices \\
\hline 113 & 2015.09 .28 & $\begin{array}{l}\text { Notice on implementing the } \\
\text { information management of } \\
\text { renewable energy power } \\
\text { generation projects }\end{array}$ & Supervision measures-OSU & NEA & Notices \\
\hline 114 & 2015.10 .28 & $\begin{array}{l}\text { Notice on carrying out the nearest } \\
\text { consumptive pilot for renewable } \\
\text { energy }\end{array}$ & Supervision measures-OSU & NDRC & Notices \\
\hline 115 & 2015.11 .27 & $\begin{array}{l}\text { Notice on issues of the use of } \\
\text { forest land in the construction of } \\
\text { photovoltaic power stations }\end{array}$ & Guidance measures-GD & SFA & Notices \\
\hline 116 & 2015.12.02 & $\begin{array}{l}\text { Notice on issuing the control } \\
\text { index of land use for photovoltaic } \\
\text { power station project }\end{array}$ & Specification measures-OS & MOLR & Notices \\
\hline 117 & 2015.12 .22 & $\begin{array}{l}\text { Notice on improving the } \\
\text { benchmark price policy of } \\
\text { onshore wind and photovoltaic } \\
\text { power generation }\end{array}$ & $\begin{array}{l}\text { Supporting measures-GS } \\
\text { Specification measures-OS }\end{array}$ & NDRC & Notices \\
\hline 118 & 2016.01.01 & $\begin{array}{l}\text { Notice of the Ministry of Finance } \\
\text { and the National Development } \\
\text { and Reform Commission on } \\
\text { Issues concerning Raising the } \\
\text { Collection Rate of the Renewable } \\
\text { Energy Development Fund }\end{array}$ & $\begin{array}{l}\text { Guidance measures-GI } \\
\text { Supporting measures-FIS }\end{array}$ & MOF, NDRC & Notices \\
\hline
\end{tabular}


Table A2. Cont.

\begin{tabular}{|c|c|c|c|c|c|}
\hline Num & Time & Policy Name & Policy Measure & Policy Department & Policy Type \\
\hline 119 & 2016.01.11 & $\begin{array}{l}\text { Notice on doing well the } \\
\text { connection between PV power } \\
\text { generation project and national } \\
\text { renewable energy information } \\
\text { management platform }\end{array}$ & Supervision measures-OSU & NEA & Notices \\
\hline 120 & 2016.02 .05 & $\begin{array}{l}\text { Notice on doing well the } \\
\text { consumptive work for the } \\
\text { renewable energy in northeast, } \\
\text { north and northwest Regions }\end{array}$ & Supervision measures-OSU & NEA & Notices \\
\hline 121 & 2016.02 .29 & $\begin{array}{l}\text { Guiding opinions on establishing } \\
\text { the guiding system for the } \\
\text { development and utilization of } \\
\text { renewable energy }\end{array}$ & $\begin{array}{l}\text { Supporting measures-IS } \\
\text { Supervision measures-OSU }\end{array}$ & NEA & Measures \\
\hline 122 & 2016.03 .23 & $\begin{array}{l}\text { Opinions on implementing the } \\
\text { poverty alleviation work of } \\
\text { photovoltaic power generation }\end{array}$ & $\begin{array}{c}\text { Guidance measures-GI } \\
\text { Supporting measures-FS, FIS, } \\
\text { GS } \\
\text { Specification measures-TSP } \\
\text { Supervision measures-OSU }\end{array}$ & NDRC, SC, NEA & Measures \\
\hline 123 & 2016.03 .24 & $\begin{array}{l}\text { Notice of the National } \\
\text { Development and Reform } \\
\text { Commission on Issuing the } \\
\text { Measures for the Administration } \\
\text { of the Guaranteed Buyout of } \\
\text { Electricity Generated by } \\
\text { Renewable Energy Resources }\end{array}$ & $\begin{array}{l}\text { Supporting measures-GS } \\
\text { Supervision measures-OSU }\end{array}$ & NDRC & Measures \\
\hline 124 & 2016.04 .14 & $\begin{array}{l}\text { Notice on Issuing the statistical } \\
\text { report forms of renewable energy } \\
\text { utilization }\end{array}$ & Supervision measures-OSU & NEA & Notices \\
\hline 125 & 2016.05 .27 & $\begin{array}{l}\text { Notice on doing well the full } \\
\text { acquisition management of wind } \\
\text { power and photovoltaic power } \\
\text { generation }\end{array}$ & $\begin{array}{l}\text { Supporting measures-GS } \\
\text { Specification measures-OS }\end{array}$ & NDRC, NEA & Notices \\
\hline 126 & 2016.06 .03 & $\begin{array}{l}\text { Notice on Issuing the construction } \\
\text { implementation plan of } \\
\text { photovoltaic power generation in } \\
2016\end{array}$ & $\begin{array}{c}\text { Guidance measures-GI } \\
\text { Supporting measures-FIS } \\
\text { Specification measures-TSP } \\
\text { Supervision measures-OSU }\end{array}$ & NEA & Notices \\
\hline 127 & 2016.07.14 & $\begin{array}{l}\text { Trial measures on the preferential } \\
\text { generation for the renewable } \\
\text { energy peak unit }\end{array}$ & Supervision measures-OSU & NDRC, NEA & Measures \\
\hline 128 & 2016.07.25 & $\begin{array}{l}\text { Notice of the Ministry of Finance } \\
\text { and the State Administration of } \\
\text { Taxation on Continuing the } \\
\text { Implementation of the } \\
\text { Value-added Tax Policy for } \\
\text { Photovoltaic Power Generation }\end{array}$ & $\begin{array}{l}\text { Guidance measures-GI } \\
\text { Supporting measures-FIS }\end{array}$ & MOF,SAT & Notices \\
\hline 129 & 2016.10.17 & $\begin{array}{l}\text { Notice on issuing the first batch of } \\
\text { photovoltaic poverty alleviation } \\
\text { projects }\end{array}$ & $\begin{array}{l}\text { Guidance measures-GI, GD } \\
\text { Supporting measures-FS, GS } \\
\text { Supervision measures-OSU }\end{array}$ & NEA, SC & Notices \\
\hline 130 & 2016.10 .27 & $\begin{array}{l}\text { Notice on Issuing the 13th } \\
\text { Five-Year work plan for } \\
\text { controlling greenhouse gas } \\
\text { emissions }\end{array}$ & Guidance measures-GI & SC & Notices \\
\hline 131 & 2016.11.29 & $\begin{array}{l}\text { Notice on issuing the " } 13 \text { th } \\
\text { Five-Year Plan" for the } \\
\text { development of national strategic } \\
\text { emerging industry }\end{array}$ & $\begin{array}{l}\text { Guidance measures-GI } \\
\text { Supporting measures-IS }\end{array}$ & SC & $\begin{array}{l}\text { Opinions and } \\
\text { Rules }\end{array}$ \\
\hline 132 & 2016.12 .08 & $\begin{array}{l}\text { Notice on issuing the " } 13 \text { th } \\
\text { Five-Year Plan" for the solar } \\
\text { development }\end{array}$ & $\begin{array}{c}\text { Guidance measures-GD } \\
\text { Supporting measures-PS, TS, } \\
\text { PT, GS } \\
\text { Specification measures-OS, } \\
\text { TSP } \\
\text { Supervision measures-QS, } \\
\text { OSU }\end{array}$ & NEA & $\begin{array}{l}\text { Opinions and } \\
\text { Rules }\end{array}$ \\
\hline 133 & 2016.12.10 & $\begin{array}{l}\text { Notice on issuing the " } 13 \text { th } \\
\text { Five-Year Plan" for the } \\
\text { development of renewable energy }\end{array}$ & $\begin{array}{c}\text { Guidance measures-GD } \\
\text { Supporting measures-IS, PS, } \\
\text { TS, GS } \\
\text { Specification measures-TSP } \\
\text { Supervision measures-OSU }\end{array}$ & NDRC & $\begin{array}{l}\text { Opinions and } \\
\text { Rules }\end{array}$ \\
\hline
\end{tabular}


Table A2. Cont.

\begin{tabular}{|c|c|c|c|c|c|}
\hline Num & Time & Policy Name & Policy Measure & Policy Department & Policy Type \\
\hline 134 & 2016.12 .26 & $\begin{array}{l}\text { Notice on adjusting the } \\
\text { benchmark price of onshore wind } \\
\text { and photovoltaic power } \\
\text { generation }\end{array}$ & $\begin{array}{c}\text { Guidance measures-GI } \\
\text { Supporting measures-FIS, GS } \\
\text { Specification measures-OS }\end{array}$ & NDRC & Notices \\
\hline \multicolumn{6}{|c|}{ Beijing } \\
\hline 135 & 2009.12 .27 & $\begin{array}{l}\text { Guidance of accelerate the } \\
\text { development and utilization of } \\
\text { solar energy to promote industrial } \\
\text { development }\end{array}$ & $\begin{array}{c}\text { Guidance measures-GI, } \\
\text { GDSupporting measures-FS, } \\
\text { TS, PS } \\
\text { Specification measures-TSP } \\
\text { Supervision measures-OSU }\end{array}$ & DRC & Measures \\
\hline 136 & 2011.01 .31 & $\begin{array}{l}\text { Notice on continue to declare } \\
\text { solar photovoltaic building } \\
\text { integration demonstration project } \\
\text { application }\end{array}$ & $\begin{array}{l}\text { Guidance measures-FIS } \\
\text { Supporting measures-PS } \\
\text { Specification measures-TSP }\end{array}$ & $\mathrm{CC}$ & Notices \\
\hline 137 & 2012.01 .31 & $\begin{array}{l}\text { Notice on } 2012 \text { Beijing solar } \\
\text { photovoltaic building } \\
\text { demonstration }\end{array}$ & $\begin{array}{l}\text { Supporting measures-FIS, PS } \\
\text { Specification measures-TSP }\end{array}$ & $\mathrm{CC}$ & Notices \\
\hline 138 & 2012.11.12 & $\begin{array}{l}\text { Notice on continue to declare } \\
\text { solar photovoltaic building } \\
\text { integration demonstration project } \\
\text { application }\end{array}$ & $\begin{array}{l}\text { Supporting measures-FIS, } \\
\text { PSSpecification measures-TSP }\end{array}$ & $\mathrm{CC}$ & Notices \\
\hline 139 & 2014.7.25 & $\begin{array}{l}\text { Notice on Issuing the Interim } \\
\text { Measures for management of } \\
\text { distributed photovoltaic power } \\
\text { generation project in Beijing }\end{array}$ & Supporting measures-PS & DRC & Notices \\
\hline 140 & 2015.8.18 & $\begin{array}{l}\text { Notice on the issuance of Beijing } \\
\text { distributed PV incentive fund } \\
\text { management approach }\end{array}$ & Supporting measures-GS & DRC & Notices \\
\hline \multicolumn{6}{|c|}{ Tianjin province } \\
\hline 141 & 2011.02 .12 & $\begin{array}{l}\text { Notice on price subsidies for } \\
\text { renewable energy projects and } \\
\text { additional funds advance }\end{array}$ & Supporting measures-GS & PB & Notices \\
\hline 142 & 2015.10 .22 & $\begin{array}{l}\text { Notice on Further Regulating the } \\
\text { Construction and Management of } \\
\text { Photovoltaic Power Generation } \\
\text { Projects }\end{array}$ & $\begin{array}{l}\text { Supporting measures-GS } \\
\text { Specification measures-OS } \\
\text { Supervision measures-OSU }\end{array}$ & DRC & Notices \\
\hline \multicolumn{6}{|c|}{ Hebei province } \\
\hline 143 & 2010.10 .22 & $\begin{array}{l}\text { Guiding opinions on promoting } \\
\text { the development of photovoltaic } \\
\text { industry }\end{array}$ & $\begin{array}{c}\text { Guidance measures-GI, } \\
\text { GDSupporting measures-FIS, } \\
\text { FS, TS, GS, IS, PT } \\
\text { Specification measures-TSP }\end{array}$ & PG & Measures \\
\hline 144 & 2011.08 .24 & $\begin{array}{l}\text { Notice on Laiyuan Xintian Wind } \\
\text { Energy Ltd solar power tariff }\end{array}$ & Supporting measures-GS & PB & Notices \\
\hline 145 & 2015.05 .22 & $\begin{array}{l}\text { Notice on the construction of } \\
\text { photovoltaic power generation } \\
\text { project }\end{array}$ & Supporting measures-GS & DRC & Notices \\
\hline 146 & 2015.07.07 & $\begin{array}{l}\text { Notice on price policy in our } \\
\text { province distributed photovoltaic } \\
\text { application key demonstration } \\
\text { village project }\end{array}$ & Supporting measures-GS & PB & Notices \\
\hline 147 & 2015.08.12 & $\begin{array}{l}\text { The guidance on further } \\
\text { regulating the photovoltaic power } \\
\text { generation project management }\end{array}$ & $\begin{array}{l}\text { Guidance measures-GI } \\
\text { Supporting measures-FIS, GS } \\
\text { Specification measures-OS } \\
\text { Supervision measures-OSU }\end{array}$ & DRC & Measures \\
\hline 148 & 2015.11.12 & $\begin{array}{l}\text { Notice on Issuing the action plan } \\
\text { for the construction of renewable } \\
\text { energy demonstration zone in } \\
\text { Hebei, Zhangiakou (2015-2017 } \\
\text { years) }\end{array}$ & $\begin{array}{c}\text { Supporting measures-IS, FIS, } \\
\text { FS, PT }\end{array}$ & PG & Notices \\
\hline 149 & 2015.12 .18 & $\begin{array}{l}\text { Notice on strengthening the } \\
\text { construction of solar photovoltaic } \\
\text { application work }\end{array}$ & $\begin{array}{l}\text { Guidance measures-GI, GD } \\
\text { Supporting measures-FIS } \\
\text { Specification measures-TSP } \\
\text { Supervision measures-OSU }\end{array}$ & $\mathrm{CC}$ & Notices \\
\hline 150 & 2016.04 .29 & $\begin{array}{l}\text { Notice on poverty alleviation and } \\
\text { development on the } \\
\text { implementation of PV poverty } \\
\text { alleviation program } 2016\end{array}$ & Supporting measures-PS & DRC & Notices \\
\hline
\end{tabular}


Table A2. Cont.

\begin{tabular}{|c|c|c|c|c|c|}
\hline Num & Time & Policy Name & Policy Measure & Policy Department & Policy Type \\
\hline 151 & 2016.10 .14 & $\begin{array}{l}\text { Notice on the issuance of Hebei } \\
\text { Province renewable energy } \\
\text { development "13th Five-Year } \\
\text { Plan" }\end{array}$ & $\begin{array}{l}\text { Supporting measures-IS, PS, } \\
\text { TS, GS } \\
\text { Supervision measures-OSU } \\
\text { Specification measures-TSP } \\
\text { Guidance measures-GD, GI }\end{array}$ & DRC & Notices \\
\hline 152 & 2016.10 .19 & $\begin{array}{l}\text { Notice on issuing the first batch of } \\
\text { ordinary grid photovoltaic power } \\
\text { generation project plan in } 2016\end{array}$ & Supporting measures-GS & DRC & Notices \\
\hline 153 & 2016.12 .29 & $\begin{array}{l}\text { Notice on the third batch of } \\
\text { ordinary grid photovoltaic power } \\
\text { generation project plan }\end{array}$ & Supporting measures-GS & DRC & Notices \\
\hline \multicolumn{6}{|c|}{ Shanxi province } \\
\hline 154 & 2010.10 .27 & $\begin{array}{l}\text { Notice on approving the } \\
\text { establishment of a notice of } \\
\text { photovoltaic materials and } \\
\text { Devices Engineering Technology } \\
\text { Research Center }\end{array}$ & Supporting measures-TS & $\begin{array}{l}\text { Provincial Department } \\
\text { of science and } \\
\text { technology }\end{array}$ & Notices \\
\hline 155 & 2014.02 .08 & $\begin{array}{l}\text { The implementation opinions on } \\
\text { promoting the healthy } \\
\text { development of the PV industry }\end{array}$ & $\begin{array}{l}\text { Supporting measures-FIS, FS, } \\
\text { GS, PS } \\
\text { Specification measures-TSP, } \\
\text { PSP }\end{array}$ & PG & Measures \\
\hline 156 & 2016.04.18 & $\begin{array}{l}\text { Notice on issuing related to } \\
\text { photovoltaic poverty alleviation } \\
\text { project in } 2016\end{array}$ & Supporting measures-PS & PG & Notices \\
\hline 157 & 2016.06.17 & $\begin{array}{l}\text { Guiding opinions on concerning } \\
\text { photovoltaic poverty alleviation } \\
\text { work }\end{array}$ & $\begin{array}{c}\text { Guidance measures-GI } \\
\text { Supporting measures-PS, FIS, } \\
\text { FS } \\
\text { Specification measures-TSP } \\
\text { Supervision measures-OSU }\end{array}$ & PG & Measures \\
\hline 158 & 2016.08 .25 & $\begin{array}{l}\text { Notice on issuing indicators of } \\
\text { photovoltaic power generation } \\
\text { projects }\end{array}$ & Supporting measures-GS & DRC & Notices \\
\hline \multicolumn{6}{|c|}{ Nei Monggol } \\
\hline 159 & 2013.12 .31 & $\begin{array}{l}\text { Notice on the issuance of the } \\
\text { Inner Mongolia Autonomous } \\
\text { Region } 2020 \text { 2013—solar power } \\
\text { development plan }\end{array}$ & $\begin{array}{l}\text { Supporting measures-IS, } \\
\text { GSSupervision measures-OSU }\end{array}$ & DRC & Notices \\
\hline 160 & 2014.08 .06 & $\begin{array}{l}\text { The opinions on promoting the } \\
\text { development of photovoltaic } \\
\text { industry }\end{array}$ & $\begin{array}{l}\text { Supporting measures-TS, } \\
\text { PSSpecification measures-PSP }\end{array}$ & PG & Measures \\
\hline 161 & 2015.03 .13 & $\begin{array}{l}\text { Guidance on the establishment of } \\
\text { renewable energy protection of } \\
\text { the acquisition of long-term } \\
\text { mechanism }\end{array}$ & $\begin{array}{l}\text { Guidance measures-GI } \\
\text { Supporting measures-GS }\end{array}$ & PG & Measures \\
\hline 162 & 2016.01 .20 & $\begin{array}{l}\text { Notice issued on the } \\
\text { implementation of district } 2015 \\
\text { Annual Supplement of } \\
\text { photovoltaic power generation } \\
\text { index construction scheme and } \\
\text { relevant problems in construction } \\
\text { projects }\end{array}$ & $\begin{array}{l}\text { Specification measures-OS } \\
\text { Supervision measures-OSU }\end{array}$ & DRC & Notices \\
\hline 163 & 2016.07.14 & $\begin{array}{l}\text { Notice on Further Strengthening } \\
\text { the management of photovoltaic } \\
\text { power generation projects in our } \\
\text { region }\end{array}$ & Specification measures-OS & DRC & Notices \\
\hline 164 & 2016.07.28 & $\begin{array}{l}\text { Notice on the issuance of the Inner } \\
\text { Mongolia Autonomous Region } \\
\text { ordinary photovoltaic power } \\
\text { plant project notice Competitive } \\
\text { Allocation Trial Measures }\end{array}$ & $\begin{array}{c}\text { Specification measures-OS, } \\
\text { TSP }\end{array}$ & DRC & Notices \\
\hline 165 & 2016.09 .13 & $\begin{array}{l}\text { Guidance on the implementation } \\
\text { of the poverty relief work of } \\
\text { photovoltaic power generation }\end{array}$ & $\begin{array}{c}\text { Guidance measures-GI } \\
\text { Supporting measures-FS, GS, } \\
\text { PS } \\
\text { Specification measures-TSP } \\
\text { Supervision measures-QS }\end{array}$ & PG & Measures \\
\hline
\end{tabular}


Table A2. Cont.

\begin{tabular}{|c|c|c|c|c|c|}
\hline Num & Time & Policy Name & Policy Measure & Policy Department & Policy Type \\
\hline \multicolumn{6}{|c|}{ Liaoning province } \\
\hline 166 & 2011.11.06 & $\begin{array}{l}\text { Notice on the implementation of } \\
\text { solar photovoltaic subsidies }\end{array}$ & Supporting measures-GS & DRC & Notices \\
\hline 167 & 2016.02 .22 & $\begin{array}{l}\text { Notice on implementation policy } \\
\text { of tariff and tariff subsidy for } \\
\text { distributed photovoltaic power } \\
\text { generation projects }\end{array}$ & Supporting measures-GS & PB & Notices \\
\hline \multicolumn{6}{|c|}{ Jilin province } \\
\hline 168 & 2012.06 .13 & $\begin{array}{l}\text { Notice on printing and } \\
\text { distributing the measures for } \\
\text { quality acceptance of renewable } \\
\text { energy construction application } \\
\text { projects in Jilin province }\end{array}$ & Specification measures-OS & $\mathrm{CC}$ & Notices \\
\hline \multicolumn{6}{|c|}{$\begin{array}{ll}\text { Heilongjiang province } \\
\end{array}$} \\
\hline 169 & 2008.01 .18 & $\begin{array}{l}\text { Heilongjiang Province, rural } \\
\text { development and utilization of } \\
\text { renewable energy regulations }\end{array}$ & $\begin{array}{c}\text { Guidance measures-GD } \\
\text { Supporting measures-FIS, FS, } \\
\text { TS, PT } \\
\text { Specification measures-PSP, } \\
\text { TSP }\end{array}$ & PG & $\begin{array}{l}\text { Opinions and } \\
\text { Rules }\end{array}$ \\
\hline 170 & 2015.04.17 & $\begin{array}{l}\text { Regulations on the development } \\
\text { and utilization of renewable } \\
\text { energy in rural areas of } \\
\text { Heilongjiang (2015 Amendment) }\end{array}$ & $\begin{array}{c}\text { Guidance measures-GD } \\
\text { Supporting measures-FIS, FS, } \\
\text { TS, PT } \\
\text { Specification measures-PSP, } \\
\text { TSP }\end{array}$ & PG & $\begin{array}{l}\text { Opinions and } \\
\text { Rules }\end{array}$ \\
\hline 171 & 2016.06 .21 & $\begin{array}{l}\text { Notices on the issuance of } 2016 \\
\text { photovoltaic power plant project } \\
\text { in Heilongiiang Province ordinary } \\
\text { competitive allocation scheme }\end{array}$ & Specification measures-OS & DRC & Notices \\
\hline \multicolumn{6}{|c|}{$\begin{array}{ll}\text { Shanghai province } \\
\end{array}$} \\
\hline 172 & 2010.11 .18 & $\begin{array}{l}\text { Notice on the allocation of } \\
\text { renewable energy and new energy } \\
\text { support funds for the city in } 2010\end{array}$ & Supporting measures-FIS & DRC & Notices \\
\hline 173 & 2013.11.22 & $\begin{array}{l}\text { Notice on promoting the healthy } \\
\text { development of the PV industry } \\
\text { on the implementation plan }\end{array}$ & $\begin{array}{l}\text { Supporting measures-FS; TS; } \\
\text { PT } \\
\text { Specification measures-TSP }\end{array}$ & PG & Notices \\
\hline 174 & 2014.04 .04 & $\begin{array}{l}\text { Notice on carrying out the } \\
\text { declaration of scale application } \\
\text { construction scale of distributed } \\
\text { photovoltaic power generation in } \\
2014\end{array}$ & Supporting measures-GS & DRC & Notices \\
\hline 175 & 2014.07.01 & $\begin{array}{l}\text { Notice on issued } 2014 \text { annual } \\
\text { distributed PV annual new } \\
\text { construction scale }\end{array}$ & Supporting measures-GS & DRC & Notices \\
\hline 176 & 2014.10 .27 & $\begin{array}{l}\text { Notice on printing and } \\
\text { distributing the regulations for } \\
\text { the management of photovoltaic } \\
\text { power generation projects in } \\
\text { Shanghai }\end{array}$ & $\begin{array}{l}\text { Specification measures-OS } \\
\text { Supervision measures-OSU }\end{array}$ & DRC & Notices \\
\hline 177 & 2015.07 .06 & $\begin{array}{l}\text { Notice on issued } 2015 \text { annual } \\
\text { implementation plan of the } \\
\text { construction of photovoltaic } \\
\text { power generation }\end{array}$ & Supporting measures-GS & DRC & Notices \\
\hline 178 & 2016.11 .02 & $\begin{array}{l}\text { Notice on Issuing the measures } \\
\text { for supporting the special funds } \\
\text { for the development of renewable } \\
\text { energy and new energy in } \\
\text { Shanghai (2016 Revision) }\end{array}$ & Supporting measures-FIS, GS & DRC & Notices \\
\hline \multicolumn{6}{|c|}{ Jiangsu procvince } \\
\hline 179 & 2009.06.19 & $\begin{array}{l}\text { Notice on Forwarding the } \\
\text { provincial development and } \\
\text { Reform Commission of Jiangsu } \\
\text { province photovoltaic power } \\
\text { generation propulsion views }\end{array}$ & $\begin{array}{c}\text { Guidance measures-GI } \\
\text { Supporting measures-FIS; FS; } \\
\text { PT; PS; TS; } \\
\text { Specification measures-TSP }\end{array}$ & DRC & Notices \\
\hline 180 & 2009.10 .26 & $\begin{array}{l}\text { Notice on strengthening the } \\
\text { construction of solar photovoltaic } \\
\text { demonstration project } \\
\text { management. }\end{array}$ & $\begin{array}{l}\text { Specification measures-TSP } \\
\text { Supervision measures-QS }\end{array}$ & $\mathrm{CC}$ & Notices \\
\hline
\end{tabular}


Table A2. Cont.

\begin{tabular}{|c|c|c|c|c|c|}
\hline Num & Time & Policy Name & Policy Measure & Policy Department & Policy Type \\
\hline 181 & 2012.06 .08 & $\begin{array}{l}\text { Notice informed the Provincial } \\
\text { Energy Bureau on photovoltaic } \\
\text { power generation to continue to } \\
\text { support the policy advice }\end{array}$ & $\begin{array}{c}\text { Guidance measures-GI } \\
\text { Supporting measures-GS; FS; } \\
\text { TS }\end{array}$ & DRC & Notices \\
\hline 182 & 2014.08 .06 & $\begin{array}{l}\text { Jiangsu Provincial Price Bureau } \\
\text { on } 2014 \text { to determine the second } \\
\text { number of grid connected } \\
\text { photovoltaic power generation } \\
\text { project tariff notice }\end{array}$ & Supporting measures-GS & PB & Notices \\
\hline 183 & 2014.10 .20 & $\begin{array}{l}\text { Jiangsu Provincial Price Bureau } \\
\text { on } 2014 \text { to determine the third } \\
\text { number of grid connected } \\
\text { photovoltaic power generation } \\
\text { project tariff notice }\end{array}$ & Supporting measuresGS & PB & Notices \\
\hline 184 & 2014.10 .25 & $\begin{array}{l}\text { The opinions on promoting the } \\
\text { healthy development of } \\
\text { distributed PV }\end{array}$ & $\begin{array}{c}\text { Guidance measures-GI } \\
\text { Supervision measures-OSU } \\
\text { Specification measures-OS }\end{array}$ & DRC & Notices \\
\hline 185 & 2015.06 .05 & $\begin{array}{l}\text { Notice on Pizhou Hu Wei } \\
\text { photovoltaic power generation } \\
\text { projects electricity price }\end{array}$ & Supporting measures-GS & PB & Notices \\
\hline 186 & 2015.07.31 & $\begin{array}{l}\text { Notice on Jiangsu Longchang } \\
\text { photovoltaic power generation } \\
\text { projects electricity price }\end{array}$ & Supporting measures-GS & PB & Notices \\
\hline 187 & 2015.10 .09 & $\begin{array}{l}\text { Price Bureau of Jiangsu province } \\
\text { to determine the Funing LIREN } \\
\text { and other photovoltaic power } \\
\text { generation projects on the } \\
\text { electricity price notice }\end{array}$ & Supporting measures-GS & PB & Notices \\
\hline 188 & 2015.11.25 & $\begin{array}{l}\text { Notice of Jiangsu Provincial Price } \\
\text { Bureau on determining the tariff } \\
\text { of photovoltaic power generation } \\
\text { projects }\end{array}$ & Supporting measures-GS & PB & Notices \\
\hline 189 & 2015.12 .28 & $\begin{array}{l}\text { Notice on Jiangsu Haidong } \\
\text { photovoltaic power generation } \\
\text { projects electricity price }\end{array}$ & Supporting measures-GS & PB & Notices \\
\hline 190 & 2016.01.19 & $\begin{array}{l}\text { Notice on Jiangsu coastal GCL } \\
\text { photovoltaic power generation } \\
\text { projects electricity price }\end{array}$ & Supporting measures-GS & PB & Notices \\
\hline 191 & 2016.02 .17 & $\begin{array}{l}\text { Notice on the determination of } \\
\text { Baoying blessing the new } \\
\text { photovoltaic power generation } \\
\text { projects electricity price }\end{array}$ & Supporting measures-GS & PB & Notices \\
\hline 192 & 2016.10 .13 & $\begin{array}{l}\text { Notice of Jiangsu Provincial Price } \\
\text { Bureau on the determination of } \\
\text { Guofeng new energy photovoltaic } \\
\text { power generation projects } \\
\text { electricity price }\end{array}$ & Supporting measures-GS & PB & Notices \\
\hline 193 & 2016.11 .28 & $\begin{array}{l}\text { Notice of Jiangsu Provincial Price } \\
\text { Bureau on Danyang Corning } \\
\text { photovoltaic power generation } \\
\text { projects electricity price }\end{array}$ & Supporting measures-GS & PB & Notices \\
\hline 194 & 2016.12 .13 & $\begin{array}{l}\text { Notice of Jiangsu Provincial Price } \\
\text { Bureau on Danyang Corning } \\
\text { photovoltaic power generation } \\
\text { projects electricity price }\end{array}$ & Supporting measures-GS & $\mathrm{PB}$ & Notices \\
\hline \multicolumn{6}{|c|}{ Zhejiang province } \\
\hline 195 & 2012.05.30 & $\begin{array}{l}\text { Regulations for promoting the } \\
\text { development and utilization of } \\
\text { renewable energy in Zhejiang }\end{array}$ & $\begin{array}{l}\text { Guidance measures-GI, GD } \\
\text { Supporting measures-FIS, FS, } \\
\text { GS, IS }\end{array}$ & PG & $\begin{array}{c}\text { Opinions and } \\
\text { Rules }\end{array}$ \\
\hline 196 & 2013.09 .26 & $\begin{array}{l}\text { Implementation opinions on } \\
\text { further accelerating the } \\
\text { application of photovoltaic } \\
\text { industry to promote the healthy } \\
\text { development of the industry }\end{array}$ & $\begin{array}{l}\text { Supporting measures-GS; FIS, } \\
\text { FS, TS, } \\
\text { Specification measures-TSP }\end{array}$ & PG & Measures \\
\hline 197 & 2015.04 .27 & $\begin{array}{l}\text { Notice on Issuing the } \\
\text { management measures of special } \\
\text { funds for renewable energy } \\
\text { development in Zhejiang }\end{array}$ & Supporting measures-FIS & PEA & Notices \\
\hline
\end{tabular}


Table A2. Cont.

\begin{tabular}{|c|c|c|c|c|c|}
\hline Num & Time & Policy Name & Policy Measure & Policy Department & Policy Type \\
\hline 198 & 2016.01.19 & $\begin{array}{l}\text { Notice on the further } \\
\text { strengthening of the construction } \\
\text { of renewable energy integration } \\
\text { application work }\end{array}$ & Supporting measures-PS & $\mathrm{CC}$ & Notices \\
\hline 199 & 2016.07 .13 & $\begin{array}{l}\text { Notice on the issuance of notice of } \\
\text { both civil construction installation } \\
\text { of solar photovoltaic system } \\
\text { design guidelines }\end{array}$ & Specification measures-TSP & CC, PEA & Notices \\
\hline 200 & 2016.09 .02 & $\begin{array}{l}\text { Opinion on promoting the } \\
\text { implementation of the views of } \\
\text { Zhejiang Province million } \\
\text { households roof photovoltaic } \\
\text { project construction }\end{array}$ & $\begin{array}{l}\text { Guidance measures-GD } \\
\text { Specification measures-TSP } \\
\text { Supporting measures-GS, FS } \\
\text { Supervision measures-QS }\end{array}$ & PG & Measures \\
\hline \multicolumn{6}{|c|}{ Anhui province } \\
\hline 201 & 2011.08.10 & $\begin{array}{l}\text { Notice on strengthening the } \\
\text { implementation and management } \\
\text { of the national solar photovoltaic } \\
\text { building application } \\
\text { demonstration project }\end{array}$ & $\begin{array}{c}\text { Guidance measures-GD } \\
\text { Supervision measures-QS, } \\
\text { OSU }\end{array}$ & $\mathrm{CC}$ & Notices \\
\hline 202 & 2012.01 .06 & $\begin{array}{l}\text { Notice on the implementation of } \\
\text { the } 2012 \text { solar photovoltaic } \\
\text { building application } \\
\text { demonstration }\end{array}$ & PS & $\mathrm{CC} / \mathrm{FB}$ & Notices \\
\hline 203 & 2015.06 .17 & $\begin{array}{l}\text { Guiding opinions on the } \\
\text { implementation of photovoltaic } \\
\text { poverty alleviation }\end{array}$ & $\begin{array}{c}\text { Guidance measures-GI; } \\
\text { Supporting measures-PS; FIS; } \\
\text { FS }\end{array}$ & PG & Measures \\
\hline \multicolumn{6}{|c|}{ Fujian province } \\
\hline 204 & 2008.12 .20 & $\begin{array}{l}\text { Opinions on the joint } \\
\text { implementation of LED and solar } \\
\text { photovoltaic industry training } \\
\text { base construction work }\end{array}$ & Supporting measures-PT & $\mathrm{FB}$ & Measures \\
\hline 205 & 2016.01.06 & $\begin{array}{l}\text { Noticeon } 2015 \text { photovoltaic power } \\
\text { plant project construction } \\
\text { management work }\end{array}$ & Specification measures-OS & DRC & Notices \\
\hline 206 & 2016.11.14 & $\begin{array}{l}\text { Notice on } 2016 \text { photovoltaic } \\
\text { power plant project construction } \\
\text { supervision work }\end{array}$ & Specification measures-OS & DRC & Notices \\
\hline 207 & 2016.12.09 & $\begin{array}{l}\text { Notice on } 2014-2015 \text { years of } \\
\text { photovoltaic construction and } \\
\text { implementation plan of the } \\
\text { project construction management }\end{array}$ & Specification measures-OS & DRC & Notices \\
\hline \multicolumn{6}{|c|}{ Jiangxi province } \\
\hline 208 & 2012.03 .29 & $\begin{array}{l}\text { Notice on holding a senior } \\
\text { seminar on practice and } \\
\text { development of solar photovoltaic } \\
\text { industry }\end{array}$ & Supporting measures-PT & PG & Notice \\
\hline 209 & 2013 & $\begin{array}{l}\text { Notice on Printing and } \\
\text { Distributing Implementation Plan } \\
\text { of " } 10,000 \text { Roofs Photovoltaic } \\
\text { Generation Project of Jiangxi } \\
\text { Province (Trial)" }\end{array}$ & $\begin{array}{l}\text { Supporting measures-PS } \\
\text { Specification measures-TSP } \\
\text { Supervision measures-QS }\end{array}$ & NRC & Notice \\
\hline 210 & 2013.06 .27 & $\begin{array}{l}\text { Notice on the work of } \\
\text { demonstration project of } 10,000 \\
\text { roofs photovoltaic power } \\
\text { generation }\end{array}$ & $\begin{array}{l}\text { Supporting measures-GS } \\
\text { Supervision measures-OSU }\end{array}$ & PEA & Notice \\
\hline 211 & 2013.11.26 & $\begin{array}{l}\text { Notice on Speeding up Promotion } \\
\text { of } 10,000 \text { Roofs Photovoltaic } \\
\text { Power Generation Demonstration } \\
\text { Projects }\end{array}$ & Supervision measures-OSU & PEA & Notice \\
\hline 212 & 2014.04 .23 & $\begin{array}{l}\text { Notice on Printing and } \\
\text { Distributing the Work Plan for } \\
\text { Accelerating the Application of } \\
\text { Photovoltaic Power Generation in } \\
\text { the Province }\end{array}$ & $\begin{array}{c}\text { Guidance measures-GI } \\
\text { Supporting measures-PS, GS, } \\
\text { FS }\end{array}$ & PG & Notice \\
\hline 213 & 2015.08.07 & $\begin{array}{l}\text { Notice on further improving the } \\
\text { work of photovoltaic power } \\
\text { generation applications }\end{array}$ & $\begin{array}{l}\text { Supporting measures-GS } \\
\text { Specification measures-TSP }\end{array}$ & PG & Notice \\
\hline
\end{tabular}


Table A2. Cont.

\begin{tabular}{|c|c|c|c|c|c|}
\hline Num & Time & Policy Name & Policy Measure & Policy Department & Policy Type \\
\hline 214 & 2009.09.14 & $\begin{array}{l}\text { Notice on the development of } \\
\text { solar energy industry in } \\
\text { Shandong province (2009-2011) }\end{array}$ & $\begin{array}{c}\text { Guidance measures-GD } \\
\text { Supporting measures-FIS, FS, } \\
\text { TS, PS } \\
\text { Specification measures-PSP }\end{array}$ & NRC & Notice \\
\hline 215 & 2010.07 .01 & $\begin{array}{l}\text { Notice on support to accelerate } \\
\text { the development of the views of } \\
\text { the photovoltaic power } \\
\text { generation }\end{array}$ & $\begin{array}{c}\text { Supporting measures-GS, FIS, } \\
\text { FS }\end{array}$ & PG & Notice \\
\hline 216 & 2011.07.14 & $\begin{array}{l}\text { Notice on further improvement of } \\
\text { the pricing policy of photovoltaic } \\
\text { power generation }\end{array}$ & Supporting measures-GS & PB & Notice \\
\hline 217 & 2013.10 .24 & $\begin{array}{l}\text { Notice on Promoting the Healthy } \\
\text { Development of Renewable } \\
\text { Energy, Energy-saving and } \\
\text { Environmental-friendly Power } \\
\text { Generation Project by Price Policy }\end{array}$ & Supporting measures-GS & $\mathrm{PB}$ & Notice \\
\hline 218 & 2014.09 .29 & $\begin{array}{l}\text { Opinion on Implementing Guo Fa } \\
\text { (2013) No. } 24 \text { Document to } \\
\text { Promote the Healthy } \\
\text { Development of Photovoltaic } \\
\text { Industry }\end{array}$ & $\begin{array}{c}\text { Guidance measures-GI } \\
\text { Supporting measures-FIS, FS, } \\
\text { TS, GS } \\
\text { Specification measures-TSP }\end{array}$ & PG & Opinion \\
\hline 219 & 2015.03.09 & $\begin{array}{l}\text { Notice on Further Strengthening } \\
\text { the Construction and Operation of } \\
\text { Photovoltaic Power Generation }\end{array}$ & $\begin{array}{c}\text { Guidance measures-GI } \\
\text { Supporting measures-GS } \\
\text { Supervision measures-OSU }\end{array}$ & NRC/PEA & Notice \\
\hline 220 & 2015.08 .25 & $\begin{array}{l}\text { Notice on Issuing Special Funds } \\
\text { Investment Plan for Regional } \\
\text { Strategic Promotion of } \\
\text { Distributed Photovoltaic Power } \\
\text { Generation Project }\end{array}$ & Supporting measures-FIS & NRC/FB & Notice \\
\hline 221 & 2015.10.22 & $\begin{array}{l}\text { Notice on Carrying out the } \\
\text { Construction of Shandong } \\
\text { Province Solar Energy } \\
\text { Application Demonstration City } \\
\text { (County) }\end{array}$ & Supporting measures-PS & NRC & Notice \\
\hline 222 & 2015.11 .06 & $\begin{array}{l}\text { Notice on matters related to } \\
\text { construction of photovoltaic } \\
\text { power station in } 2015\end{array}$ & Supporting measures-GS & NRC & Notice \\
\hline 223 & 2016.06 .23 & $\begin{array}{l}\text { Notice of accelerating the } \\
\text { promotion of photovoltaic work } \\
\text { in the province }\end{array}$ & $\begin{array}{l}\text { Supporting measures-PS, FIS, } \\
\text { FS, GS }\end{array}$ & NRC & Notice \\
\hline \multicolumn{6}{|c|}{ Henan province } \\
\hline 224 & 2008.05 .05 & $\begin{array}{l}\text { Notice on the grant of subsidy } \\
\text { funds for the project of renewable } \\
\text { energy construction application }\end{array}$ & Supporting measures-FIS & FB & Notice \\
\hline 225 & 2010.10 .09 & $\begin{array}{l}\text { "Notice on Strengthening the } \\
\text { Construction Management of } \\
\text { Golden Sun Demonstration } \\
\text { Project and Solar PV Building } \\
\text { Application Demonstration } \\
\text { Project" }\end{array}$ & Supporting measures-FIS, PS & NRC & Notice \\
\hline \multicolumn{6}{|c|}{ Hunan province } \\
\hline 226 & 2009.11.12 & $\begin{array}{l}\text { Opinion on accelerating the } \\
\text { application of photovoltaic power } \\
\text { generation and lighting }\end{array}$ & $\begin{array}{c}\text { Guidance measures-GD } \\
\text { Supporting measures-PS, FIS, } \\
\text { FS, TS, PT } \\
\text { Specification measures-TSP }\end{array}$ & PG & Opinion \\
\hline 227 & 2016.01 .21 & $\begin{array}{l}\text { Notice on Further Strengthening } \\
\text { the Application and Management } \\
\text { of Renewable Energy Buildings }\end{array}$ & $\begin{array}{l}\text { Guidance measures-GD } \\
\text { Supporting measures-FIS }\end{array}$ & $\mathrm{CC}$ & Notice \\
\hline \multicolumn{6}{|c|}{ Hubei province } \\
\hline 228 & 2010.07.30 & $\begin{array}{l}\text { Rural renewable energy } \\
\text { regulations }\end{array}$ & Guidance measures-GI & PG & Regulations \\
\hline 229 & 2013.10 .21 & $\begin{array}{l}\text { Notice on Organizing Relevant } \\
\text { Enterprises to Declare the } \\
\text { Normative Bulletin of the } \\
\text { Photovoltaic Manufacturing } \\
\text { Industry }\end{array}$ & Specification measures-PSP & NRC & Notice \\
\hline
\end{tabular}


Table A2. Cont.

\begin{tabular}{|c|c|c|c|c|c|}
\hline Num & Time & Policy Name & Policy Measure & Policy Department & Policy Type \\
\hline 230 & 2014.05 .08 & $\begin{array}{l}\text { Notice on Carrying out } \\
\text { Demonstration Work of } \\
\text { Demonstration of Application of } \\
\text { Renewable Energy Building and } \\
\text { Solar PV Building }\end{array}$ & Supervision measures-OSU & $\mathrm{CC} / \mathrm{FB}$ & Notice \\
\hline \multicolumn{6}{|c|}{ Guangdong province } \\
\hline 231 & 2014.03.05 & $\begin{array}{l}\text { The opinions of the general office } \\
\text { of the people's Government of } \\
\text { Guangdong Province on } \\
\text { promoting the healthy } \\
\text { development of the PV industry }\end{array}$ & $\begin{array}{c}\text { Guidance measures-GI } \\
\text { Supporting measures-FIS, FS, } \\
\text { GS, PT, TS, IS } \\
\text { Specification measures-PSP }\end{array}$ & PG & Measures \\
\hline 232 & 2014.03 .26 & $\begin{array}{l}\text { Notice of the Guangdong } \\
\text { provincial development and } \\
\text { Reform Commission issued in } \\
2014 \text { on the annual new } \\
\text { construction scale photovoltaic } \\
\text { power generation }\end{array}$ & Supporting measures-GS & DRC & Notices \\
\hline 233 & 2014.08 .20 & $\begin{array}{l}\text { On the issuance of Guangdong } \\
\text { province solar photovoltaic } \\
\text { development plan (2014-2020) } \\
\text { Notice }\end{array}$ & $\begin{array}{c}\text { Guidance measures-GI, GD } \\
\text { Supporting measures-FIS, FS, } \\
\text { GS, IS } \\
\text { Supervisionmeasures-OSU }\end{array}$ & DRC & Notices \\
\hline 234 & 2015.01.12 & $\begin{array}{l}\text { Notice of the Guangdong } \\
\text { provincial development and } \\
\text { Reform Commission on doing a } \\
\text { good job in preparation of solar } \\
\text { energy development planning "in } \\
\text { 13th Five-Year" }\end{array}$ & Supporting measures-IS & DRC & Notices \\
\hline 235 & 2015.06 .02 & $\begin{array}{l}\text { Notice of the Guangdong } \\
\text { provincial development and } \\
\text { Reform Commission issued on } \\
2015 \text { in Guangdong Province, the } \\
\text { construction of photovoltaic } \\
\text { power generation project }\end{array}$ & $\begin{array}{l}\text { Supporting measures-GS } \\
\text { Supervision measures-OSU }\end{array}$ & DRC & Notices \\
\hline \multicolumn{6}{|c|}{ Guangxi province } \\
\hline 236 & 2016.01 .22 & $\begin{array}{l}\text { Notice of the the Guangxi Zhuang } \\
\text { Autonomous Region } \\
\text { development and Reform } \\
\text { Commission on the improvement } \\
\text { of the area of photovoltaic power } \\
\text { plant project construction } \\
\text { management work }\end{array}$ & Supervision measures-OSU & DRC & Notices \\
\hline \multicolumn{6}{|c|}{ Sichuan province } \\
\hline 237 & 2016.01 .28 & $\begin{array}{l}\text { Sichuan provincial development } \\
\text { and Reform Commission } \\
\text { forwards the national } \\
\text { development and Reform } \\
\text { Commission on the improvement } \\
\text { of onshore wind power } \\
\text { photovoltaic power generation } \\
\text { benchmark price policy notice } \\
\text { notice }\end{array}$ & Supporting measures-GS & DRC & Notices \\
\hline \multicolumn{6}{|c|}{ Guizhou province } \\
\hline 238 & 2010.10 .10 & $\begin{array}{l}\text { Notice on the organization } \\
\text { declared the } 2010 \text { provincial } \\
\text { renewable energy construction } \\
\text { application demonstration city } \\
\text { and rural areas of the County } \\
\text { demonstration special fund } \\
\text { project }\end{array}$ & Supporting measures-FIS & $\mathrm{CC} / \mathrm{FB}$ & Notices \\
\hline 239 & 2011.06 .15 & $\begin{array}{l}\text { Notice on the organization to } \\
\text { declare the provincial city of } \\
\text { application of renewable energy } \\
\text { in rural areas and Building } \\
\text { Demonstration County } \\
\text { demonstration special fund } \\
\text { project }\end{array}$ & Supporting measures-FIS & $\mathrm{CC} / \mathrm{FB}$ & Notices \\
\hline
\end{tabular}


Table A2. Cont.

\begin{tabular}{|c|c|c|c|c|c|}
\hline Num & Time & Policy Name & Policy Measure & Policy Department & Policy Type \\
\hline \multicolumn{6}{|c|}{ Yunnan province } \\
\hline 240 & 2011.04 .01 & $\begin{array}{l}\text { The measures for the } \\
\text { implementation of the access } \\
\text { system of renewable energy } \\
\text { power generation project in } \\
\text { Yunnan Province }\end{array}$ & Supporting measures-GS & DRC & Measures \\
\hline 241 & 2012.01.08 & $\begin{array}{l}\text { Notice on Application of special } \\
\text { fund project for renewable energy } \\
\text { development in } 2012\end{array}$ & Supporting measures-FIS & FB & Notices \\
\hline 242 & 2014.01.13 & $\begin{array}{l}\text { Notice on Application of special } \\
\text { fund project for renewable energy } \\
\text { development in } 2014\end{array}$ & Supporting measures-FIS & FB & Notices \\
\hline 243 & 2014.04 .01 & $\begin{array}{l}\text { Notice of Yunnan Provincial } \\
\text { People's Government on printing } \\
\text { and distributing the } \\
\text { implementation plan of } \\
\text { promoting the healthy } \\
\text { development of photovoltaic } \\
\text { industry in Yunnan }\end{array}$ & $\begin{array}{l}\text { Guidance measures-GI, GD } \\
\text { Supporting measures-GS, FIS, } \\
\text { FS } \\
\text { Specification measures-TSP, } \\
\text { PSP }\end{array}$ & PG & Notices \\
\hline \multicolumn{6}{|c|}{ Shaanxi province } \\
\hline 244 & 2009.09 .02 & $\begin{array}{l}\text { Notice of the Ministry of finance } \\
\text { of Shaanxi province and the } \\
\text { Ministry of housing and urban } \\
\text { rural development on Issuing the } \\
\text { guidelines for the application of } \\
\text { provincial solar photovoltaic } \\
\text { building application } \\
\text { demonstration projects }\end{array}$ & Supporting measures-FIS & $\mathrm{FB} / \mathrm{CC}$ & Notices \\
\hline 245 & 2009.10.14 & $\begin{array}{l}\text { Notice of Shaanxi provincial } \\
\text { Ministry of industry and } \\
\text { information technology on } \\
\text { declaring the special project of } \\
\text { solar photovoltaic and } \\
\text { semiconductor lighting industry } \\
\text { development in Shaanxi Province } \\
\text { in } 2009\end{array}$ & Supporting measures-FIS & DRC & Notices \\
\hline 246 & 2010.05 .05 & $\begin{array}{l}\text { Notice of the Shaanxi provincial } \\
\text { development and Reform } \\
\text { Commission on photovoltaic } \\
\text { power plant in our province } \\
\text { provide information about } \\
\text { franchise rights for the project }\end{array}$ & Supporting measures-IS & DRC & Notices \\
\hline 247 & 2011.05 .13 & $\begin{array}{l}\text { Notice of the Shaanxi provincial } \\
\text { development and Reform } \\
\text { Commission to submit relevant } \\
\text { materials about the "12th } \\
\text { Five-Year" solar power generation } \\
\text { project }\end{array}$ & Guidance measures-GI & DRC & Notices \\
\hline 248 & 2011.07.11 & $\begin{array}{l}\text { Notice on the issuance of the } 2011 \\
\text { provincial solar photovoltaic and } \\
\text { photothermal building } \\
\text { demonstration project reporting } \\
\text { guidelines. }\end{array}$ & Supporting measures-FIS & $\mathrm{CC} / \mathrm{FB}$ & Notices \\
\hline 249 & 2012.05.02 & $\begin{array}{l}\text { Notice of Shaanxi Provincial } \\
\text { Department of housing and urban } \\
\text { rural construction on } 2012 \text { issued } \\
\text { by the provincial solar } \\
\text { photovoltaic and photothermal } \\
\text { building demonstration project } \\
\text { reporting guidelines. }\end{array}$ & Supporting measures-FIS & $\mathrm{CC}$ & Notices \\
\hline 250 & 2012.06 .15 & $\begin{array}{l}\text { Notice of Shaanxi provincial } \\
\text { development and Reform } \\
\text { Commission on the } 2012 \\
\text { development plan of grid } \\
\text { connected photovoltaic power } \\
\text { generation project organization }\end{array}$ & Supporting measures-IS & DRC & Notices \\
\hline 251 & 2012.06 .25 & $\begin{array}{l}\text { Notice on accelerating the } \\
\text { construction of solar photovoltaic } \\
\text { applications work. }\end{array}$ & $\begin{array}{l}\text { Guidance measures-GI, GD } \\
\text { Specification measures-TSP }\end{array}$ & $\mathrm{CC}$ & Notices \\
\hline
\end{tabular}


Table A2. Cont.

\begin{tabular}{|c|c|c|c|c|c|}
\hline Num & Time & Policy Name & Policy Measure & Policy Department & Policy Type \\
\hline 252 & 2013.07.18 & $\begin{array}{l}\text { To vigorously promote the } \\
\text { development of the solar power } \\
\text { industry to speed up the notice }\end{array}$ & $\begin{array}{c}\text { Guidance measures-GI } \\
\text { Supporting measures-FIS, FS }\end{array}$ & DRC & Notices \\
\hline 253 & 2013.09 .24 & $\begin{array}{l}\text { Notice of Shaanxi provincial } \\
\text { development and Reform } \\
\text { Commission on speeding up the } \\
\text { construction of photovoltaic } \\
\text { power generation projects }\end{array}$ & $\begin{array}{l}\text { Supporting measures-GS } \\
\text { Supervision measures-OSU }\end{array}$ & DRC & Notices \\
\hline 254 & 2014.12 .04 & $\begin{array}{l}\text { The People's Government of } \\
\text { Shaanxi Province on promoting } \\
\text { the implementation of the views } \\
\text { of distributed photovoltaic power } \\
\text { generation demonstration }\end{array}$ & $\begin{array}{c}\text { Guidance measures-GD } \\
\text { Supporting measures-PS, GS, } \\
\text { FIS, FS }\end{array}$ & PG & Measures \\
\hline 255 & 2015.01.16 & $\begin{array}{l}\text { Notice on the } 2014 \text { annual } \\
\text { provincial renewable energy } \\
\text { demonstration project } \\
\text { management and acceptance } \\
\text { related matters }\end{array}$ & $\begin{array}{l}\text { Supervision measures-QS, } \\
\text { OSU }\end{array}$ & $\mathrm{CC}$ & Notices \\
\hline \multicolumn{6}{|c|}{ Gansu province } \\
\hline 256 & 2012.06 .15 & $\begin{array}{l}\text { Gansu provincial development } \\
\text { and Reform Commission on } \\
\text { Dongfang Electric (Jiuquan) } \\
\text { approved the solar power } \\
\text { generation Co. Ltd. in Suzhou } \\
\text { District Dong Dong Tan } 9 \text { MW } \\
\text { grid connected photovoltaic } \\
\text { power generation project }\end{array}$ & $\begin{array}{l}\text { Guidance measures-GD } \\
\text { Supporting measures-GS }\end{array}$ & DRC & Notice \\
\hline 257 & 2012.06 .19 & $\begin{array}{l}\text { Approved by the Gansu } \\
\text { provincial development and } \\
\text { Reform Commission on the } \\
\text { approval of the Gansu Long } \\
\text { Chang photovoltaic power } \\
\text { company limited Jinchuan district } \\
15 \mathrm{MW} \text { photovoltaic power } \\
\text { generation project }\end{array}$ & $\begin{array}{l}\text { Guidance measures-GD } \\
\text { Supporting measures-GS }\end{array}$ & DRC & Notice \\
\hline 258 & 2012.07.20 & $\begin{array}{l}\text { Gansu provincial development } \\
\text { and Reform Commission on the } \\
\text { zkenergy (Jiuquan) Amperex } \\
\text { Technology Limited approved the } \\
9 \mathrm{MW} \text { grid connected } \\
\text { photovoltaic power generation } \\
\text { project }\end{array}$ & $\begin{array}{l}\text { Guidance measures-GD } \\
\text { Supporting measures-GS }\end{array}$ & DRC & Notice \\
\hline 259 & 2012.07.20 & $\begin{array}{l}\text { Approved by the Gansu } \\
\text { provincial development and } \\
\text { Reform Commission on the } \\
\text { approval of Dong Dong Tan } \\
\text { Huadian new energy Jiuquan } \\
\text { Suzhou } 9 \text { MW grid connected } \\
\text { photovoltaic power generation } \\
\text { project }\end{array}$ & $\begin{array}{l}\text { Guidance measures-GD } \\
\text { Supporting measures-GS }\end{array}$ & DRC & Notice \\
\hline 260 & 2012.07.30 & $\begin{array}{l}\text { Approved by the Gansu } \\
\text { provincial development and } \\
\text { Reform Commission on the } \\
\text { approval of Huadian new Energy } \\
\text { Developments Ltd Jiayuguan } 9 \\
\text { MW grid connected photovoltaic } \\
\text { power generation project }\end{array}$ & $\begin{array}{l}\text { Guidance measures-GD } \\
\text { Supporting measures-GS }\end{array}$ & DRC & Notice \\
\hline 261 & 2012.08.22 & $\begin{array}{l}\text { Approved by the Gansu } \\
\text { provincial development and } \\
\text { Reform Commission on the } \\
\text { approval of Xigou mine of Gansu } \\
\text { Shenzhou photovoltaic power } \\
\text { company limited Jiayuguan } 9 \mathrm{MW} \\
\text { grid connected photovoltaic } \\
\text { power generation project }\end{array}$ & $\begin{array}{l}\text { Guidance measures-GD } \\
\text { Supporting measures-GS }\end{array}$ & DRC & Notice \\
\hline
\end{tabular}


Table A2. Cont.

\begin{tabular}{|c|c|c|c|c|c|}
\hline Num & Time & Policy Name & Policy Measure & Policy Department & Policy Type \\
\hline 262 & 2012.08 .22 & $\begin{array}{l}\text { Approved provincial } \\
\text { development and Reform } \\
\text { Commission on hydropower and } \\
\text { new energy development limited } \\
\text { liability company } \\
\text { ganzhouborough approved } 50 \\
\text { MW grid connected photovoltaic } \\
\text { power generation project }\end{array}$ & $\begin{array}{l}\text { Guidance measures-GD } \\
\text { Supporting measures-GS }\end{array}$ & DRC & Notice \\
\hline 263 & 2012.09 .29 & $\begin{array}{l}\text { Approved by the Gansu } \\
\text { provincial development and } \\
\text { Reform Commission on China } \\
\text { Hydropower Construction Group } \\
\text { New Energy Development Co. } \\
\text { Ltd. Liangzhou district approved } \\
50 \text { MW grid connected } \\
\text { photovoltaic power generation } \\
\text { project }\end{array}$ & $\begin{array}{l}\text { Guidance measures-GD } \\
\text { Supporting measures-GS }\end{array}$ & DRC & Notice \\
\hline 264 & 2012.10.24 & $\begin{array}{l}\text { Approved by the Gansu } \\
\text { provincial development and } \\
\text { Reform Commission on the } \\
\text { approval of CHINT photovoltaic } \\
\text { power generation Co. Ltd. Aksay } \\
\text { Aksay county } 10 \mathrm{MW} \text { grid } \\
\text { connected photovoltaic power } \\
\text { generation project }\end{array}$ & $\begin{array}{l}\text { Guidance measures-GD } \\
\text { Supporting measures-GS }\end{array}$ & DRC & Notice \\
\hline 265 & 2012.10 .30 & $\begin{array}{l}\text { Gansu provincial development } \\
\text { and Reform Commission } \\
\text { approved the approval of the } 9 \\
\text { MW grid connected photovoltaic } \\
\text { power generation project in } \\
\text { Wuwei Liangzhou District of the } \\
\text { Yellow River Gansu hydropower } \\
\text { Co., Ltd. }\end{array}$ & $\begin{array}{l}\text { Guidance measures-GD } \\
\text { Supporting measures-GS }\end{array}$ & DRC & Notice \\
\hline 266 & 2013.04 .17 & $\begin{array}{l}\text { Notice of the Ministry of housing } \\
\text { and urban rural development of } \\
\text { Gansu on strengthening the } \\
\text { management of national } \\
\text { renewable energy construction } \\
\text { application demonstration project }\end{array}$ & $\begin{array}{l}\text { Supervision measures-QS, } \\
\text { OSU }\end{array}$ & $\mathrm{CC}$ & Notices \\
\hline 267 & 2013.06 .24 & $\begin{array}{l}\text { Regarding the development of } \\
\text { renewable energy construction } \\
\text { application of special information } \\
\text { disclosure work notice }\end{array}$ & Supervision measures-OSU & $\mathrm{CC}$ & Notices \\
\hline 268 & 2013.12 .31 & $\begin{array}{l}\text { Gansu province to implement the } \\
\text { implementation of the State } \\
\text { Council on promoting the healthy } \\
\text { development of photovoltaic } \\
\text { industry several opinions } \\
\text { implementation plan }\end{array}$ & $\begin{array}{c}\text { Supporting measures-GS, TS, } \\
\text { FIS, FS, PT }\end{array}$ & PG & Notices \\
\hline 269 & 2014.03.10 & $\begin{array}{l}\text { Notice of Gansu provincial } \\
\text { industry and Information } \\
\text { Committee on organizing and } \\
\text { recommending key projects of } \\
\text { photovoltaic industry in } 2014\end{array}$ & Supporting measures-FS & DRC & Notices \\
\hline \multicolumn{6}{|c|}{ Qinghai province } \\
\hline 270 & 2008.04 .08 & Guidance on using solar building & $\begin{array}{c}\text { Supporting measures-FIS, TS, } \\
\text { PS }\end{array}$ & $\mathrm{CC}$ & Measures \\
\hline 271 & 2010.01 .25 & $\begin{array}{l}\text { Notice of } 20087 \text { month run public } \\
\text { renewable energy independent } \\
\text { power system maintenance cost } \\
\text { subsidies }\end{array}$ & Supporting measures-FIS & DRC & Notices \\
\hline 272 & 2010.04 .08 & $\begin{array}{l}\text { Notice of the Qinghai provincial } \\
\text { development and Reform } \\
\text { Commission agreed to carry out } \\
\text { Chinese Water Conservancy } \\
\text { Investment Corporation Golmud } \\
10 \mathrm{MW} \text { photovoltaic power grid } \\
\text { work }\end{array}$ & Supporting measures-GS & DRC & Notices \\
\hline
\end{tabular}


Table A2. Cont.

\begin{tabular}{|c|c|c|c|c|c|}
\hline Num & Time & Policy Name & Policy Measure & Policy Department & Policy Type \\
\hline 273 & 2010.04 .08 & $\begin{array}{l}\text { Notice of Qinghai provincial } \\
\text { development and Reform } \\
\text { Commission on the development } \\
\text { of Golmud } 10 \text { MW grid connected } \\
\text { photovoltaic power station of } \\
\text { Limited by Share Ltd }\end{array}$ & Supporting measures-GS & DRC & Notices \\
\hline 274 & 2010.04 .25 & $\begin{array}{l}\text { Qinghai provincial development } \\
\text { and Reform Commission on the } \\
\text { approval of notice to carry out } \\
\text { SDIC Golmud photovoltaic power } \\
\text { generation Co. Ltd. Golmud two } \\
30 \text { MW grid connected } \\
\text { photovoltaic power plant work }\end{array}$ & Supporting measures-GS & DRC & Notices \\
\hline 275 & 2010.05 .06 & $\begin{array}{l}\text { Qinghai provincial development } \\
\text { and Reform Commission on the } \\
\text { approval of China Guangdong } \\
\text { Nuclear Power Solar Energy } \\
\text { Development Company Limited } \\
\text { (Dachaidan) Notice tin Tieshan } \\
\text { two } 30 \mathrm{MW} \text { photovoltaic power } \\
\text { grid work }\end{array}$ & Supporting measures-GS & DRC & Notices \\
\hline 276 & 2011.08.04 & $\begin{array}{l}\text { Notice of the Qinghai provincial } \\
\text { development and Reform } \\
\text { Commission on the relevant } \\
\text { issues concerning the first half of } \\
\text { the province in } 2009 \text { renewable } \\
\text { energy price subsidies under the }\end{array}$ & Supporting measures-FIS & DRC & Notices \\
\hline 277 & 2011.10.10 & $\begin{array}{l}\text { Notice of the Qinghai provincial } \\
\text { development and Reform } \\
\text { Commission on the province from } \\
\text { January to September } 2010 \\
\text { renewable energy price subsidies } \\
\text { related matters }\end{array}$ & Supporting measures-FIS & DRC & Notices \\
\hline 278 & 2011.12 .30 & $\begin{array}{l}\text { Notice of Qinghai provincial } \\
\text { development and Reform } \\
\text { Commission on the province in } \\
2011 \text { the completion of } \\
\text { photovoltaic power tariff }\end{array}$ & Supporting measures-GS & DRC & Notices \\
\hline 279 & 2012.07.05 & $\begin{array}{l}\text { Approved on Golmud Huadian } \\
\text { Solar Power Co. Ltd. Golmud two } \\
20 \mathrm{MW} \text { grid connected } \\
\text { photovoltaic power generation } \\
\text { project environmental impact } \\
\text { report }\end{array}$ & Guidance measures-GD & DRC & Notice \\
\hline 280 & 2014.04 .01 & $\begin{array}{l}\text { The opinions of the general office } \\
\text { of the People's Government of } \\
\text { Qinghai Province on promoting } \\
\text { the healthy development of } \\
\text { photovoltaic industry in Qinghai }\end{array}$ & $\begin{array}{c}\text { Supporting measures-TS, FIS, } \\
\text { FS, GS }\end{array}$ & PG & Measures \\
\hline 281 & 2015.02 .03 & $\begin{array}{l}\text { Qinghai provincial development } \\
\text { and Reform Commission on } \\
\text { notice of the distributed } \\
\text { photovoltaic power generation }\end{array}$ & $\begin{array}{l}\text { Supporting measures-GS } \\
\text { Supervision measures-OSU }\end{array}$ & DRC & Notices \\
\hline 282 & 2015.06 .29 & $\begin{array}{l}\text { Notify the office of Qinghai } \\
\text { Provincial People's government } \\
\text { poverty alleviation Bureau and } \\
\text { other departments of Qinghai } \\
\text { Province on } 2015 \text { PV poor pilot } \\
\text { scheme }\end{array}$ & Supporting measures-FIS, GS & PG & Notices \\
\hline 283 & 2016.09.18 & $\begin{array}{l}\text { Notice of the Qinghai provincial } \\
\text { development and Reform } \\
\text { Commission on the issuance of } \\
\text { Qinghai Province in } 2016 \text { the first } \\
\text { batch of ordinary scale } \\
\text { photovoltaic power plant project } \\
\text { bidding scheme index }\end{array}$ & Supervision measures-OSU & DRC & Notices \\
\hline
\end{tabular}


Table A2. Cont.

\begin{tabular}{|c|c|c|c|c|c|}
\hline Num & Time & Policy Name & Policy Measure & Policy Department & Policy Type \\
\hline \multicolumn{6}{|c|}{ Ningxia province } \\
\hline 284 & 2010.04 .20 & $\begin{array}{l}\text { Approved by the the Ningxia Hui } \\
\text { Autonomous Region Bureau on } \\
\text { my area of Ningxia sun Hill four } \\
\text { solar photovoltaic power station } \\
\text { temporary tariff }\end{array}$ & Supporting measures-GS & PB & Notice \\
\hline 285 & 2010.08 .02 & $\begin{array}{l}\text { On the issuance of the Ningxia } \\
\text { Hui Autonomous Region } \\
\text { planning and architectural } \\
\text { applications of renewable energy } \\
\text { development (2010-2020) Notice }\end{array}$ & $\begin{array}{c}\text { Guidance measures-GI, GD } \\
\text { Supporting measures-FIS, FS, } \\
\text { IS, PT } \\
\text { Specification measures-TSP } \\
\text { Supervision measures-QS, } \\
\text { OSU }\end{array}$ & PG & Notices \\
\hline 286 & 2014.08 .22 & $\begin{array}{l}\text { Notice of the the Ningxia Hui } \\
\text { Autonomous Region Bureau of } \\
\text { Yongning County of Tiexi Hui } \\
\text { Min Ning town primary school } 90 \\
\text { kW distributed photovoltaic } \\
\text { power generation projects } \\
\text { electricity price }\end{array}$ & Supporting measures-GS & PB & Notices \\
\hline 287 & 2015.11 .25 & $\begin{array}{l}\text { The Ningxia Hui Autonomous } \\
\text { Region Bureau of price notice on } \\
\text { renewable energy power } \\
\text { generation projects of Ningxia } \\
\text { Yanchi wind farm (Chen Jiliang) } \\
\text { capital Gan } 49.5 \mathrm{MW} \text { wind power } \\
\text { project }\end{array}$ & Supporting measures-GS & PB & Notices \\
\hline 288 & 2015.12 .30 & $\begin{array}{l}\text { Notice of the the Ningxia Hui } \\
\text { Autonomous Region Bureau of } \\
\text { Wuzhong City Baita wind power } \\
\text { limited Wind } 1 \text { wind farms two } \\
\text { phase expansion project and other } \\
\text { renewable energy power } \\
\text { generation projects electricity } \\
\text { price }\end{array}$ & Supporting measures-GS & PB & Notices \\
\hline 289 & 2015.12 .31 & $\begin{array}{l}\text { The Ningxia Hui Autonomous } \\
\text { Region Bureau of Wuzhong } \\
\text { Longyuan Wind Power Co. Ltd ( } 3 \\
\text { Yanchi pond, Su Bu Jing, Hua Ma } \\
\text { Chi) Notice of wind and other } \\
\text { renewable energy power } \\
\text { generation projects electricity } \\
\text { price }\end{array}$ & Supporting measures-GS & PB & Notices \\
\hline 290 & 2016.01.05 & $\begin{array}{l}\text { Notice of the general office of the } \\
\text { People's Government of the } \\
\text { Ningxia Hui Autonomous Region } \\
\text { on Issuing the guiding opinions } \\
\text { on the allocation of resources for } \\
\text { photovoltaic power station } \\
\text { projects and for the record and } \\
\text { construction management of } \\
\text { photovoltaic power station } \\
\text { projects }\end{array}$ & Specification measures-TSP & PB & Notices \\
\hline 291 & 2016.01.08 & $\begin{array}{l}\text { Notice of the the Ningxia Hui } \\
\text { Autonomous Region Bureau of } \\
\text { Beijing Helan ponds photovoltaic } \\
\text { demonstration project and } \\
\text { Guoxin Yanchi photovoltaic and } \\
\text { livestock processing integration } \\
\text { projects tariff }\end{array}$ & Supporting measures-GS & PB & Notices \\
\hline 292 & 2016.02 .03 & $\begin{array}{l}\text { The Ningxia Hui Autonomous } \\
\text { Region Price Bureau, autonomous } \\
\text { region Price Bureau on Ningxia } \\
\text { Bao Bao central two phase } \\
\text { photovoltaic power station and } \\
\text { other renewable energy } \\
\text { generation projects on the } \\
\text { electricity price notice }\end{array}$ & Supporting measures-GS & PB & Notices \\
\hline
\end{tabular}


Table A2. Cont.

\begin{tabular}{|c|c|c|c|c|c|}
\hline Num & Time & Policy Name & Policy Measure & Policy Department & Policy Type \\
\hline 293 & 2016.03 .24 & $\begin{array}{l}\text { The Ningxia Hui Autonomous } \\
\text { Region Price Bureau on division } \\
\text { three Pingluo } 50 \mathrm{MWp} \\
\text { photovoltaic power plant and } \\
\text { other renewable energy power } \\
\text { generation projects tariff } \\
\text { notification }\end{array}$ & Supporting measures-GS & PB & Notices \\
\hline 294 & 2016.06 .07 & $\begin{array}{l}\text { Notice of the the Ningxia Hui } \\
\text { Autonomous Region People's } \\
\text { Government Office forwarded the } \\
\text { autonomous region development } \\
\text { and Reform Commission and } \\
\text { other departments on the } \\
\text { opinions to further standardize } \\
\text { the construction management of } \\
\text { photovoltaic power station }\end{array}$ & Specification measures-OS & DRC & Notices \\
\hline \multicolumn{6}{|c|}{$\begin{array}{ll}\text { Xinjiang province } \\
\end{array}$} \\
\hline 295 & 2011.12.01 & $\begin{array}{l}\text { Regarding the development of } \\
\text { new electronic materials, notify } \\
\text { the basic survey of solar } \\
\text { photovoltaic industry }\end{array}$ & Supporting measures-IS & DRC & Notices \\
\hline 296 & 2012.03.16 & $\begin{array}{l}\text { On the issuance of the Xinjiang } \\
\text { Uygur Autonomous Region solar } \\
\text { energy photovoltaic industry } \\
\text { development plan (2011-2015) } \\
\text { Notice }\end{array}$ & $\begin{array}{l}\text { Supporting measures-IS, GS, } \\
\text { FIS, PT }\end{array}$ & PG & Notices \\
\hline 297 & 2013.08.16 & $\begin{array}{l}\text { Notice on accelerating Xinjiang } \\
\text { without electricity power supply } \\
\text { engineering and photovoltaic } \\
\text { independent power supply } \\
\text { project EIA related matters }\end{array}$ & Guidance measures-GD & DRC & Notices \\
\hline 298 & 2014.03.03 & $\begin{array}{l}\text { Notice of the Xinjiang } \\
\text { autonomous region development } \\
\text { and Reform Commission and the } \\
\text { Ministry of Finance on printing } \\
\text { and distributing the } \\
\text { administrative measures for the } \\
\text { independent power supply } \\
\text { project of photovoltaic power } \\
\text { construction in Xinjiang without } \\
\text { electricity area }\end{array}$ & Supervision measuresOSU & DRC & Notices \\
\hline \multicolumn{6}{|c|}{ Hainan province } \\
\hline 299 & 2008.09 .25 & $\begin{array}{l}\text { Opinions on promoting the } \\
\text { large-scale utilization of solar } \\
\text { energy in Hainan }\end{array}$ & $\begin{array}{c}\text { Guidance measures-GI, GD } \\
\text { Supporting measures-FIS, FS, } \\
\text { TS } \\
\text { Specification measures-TSP }\end{array}$ & DRC & Measures \\
\hline 300 & 2012.12 .29 & $\begin{array}{l}\text { Notice of Hainan Provincial Price } \\
\text { Bureau of Haikou national hi tech } \\
\text { Development Zone, photovoltaic } \\
\text { power generation demonstration } \\
\text { project tariff, etc. }\end{array}$ & Supporting measures-GS & $\mathrm{PB}$ & Notices \\
\hline 301 & 2013.07.26 & $\begin{array}{l}\text { Notice of Hainan Provincial Price } \\
\text { Bureau on cross-strait new energy } \\
\text { cooperation Hainan Aerospace } 50 \\
\text { MW photovoltaic power } \\
\text { generation demonstration of } \\
\text { golden sun demonstration project, } \\
\text { electricity price }\end{array}$ & Supporting measures-GS & PB & Notices \\
\hline 302 & 2013.12.24 & $\begin{array}{l}\text { Hainan Province Price Bureau of } \\
\text { Hainan City Economic } \\
\text { Development Zone, Jinsheng } \\
\text { building materials mall } \\
\text { concentrated photovoltaic power } \\
\text { generation projects such as tariff } \\
\text { notification }\end{array}$ & Supporting measures-GS & $\mathrm{PB}$ & Notices \\
\hline 303 & 2013.12.27 & $\begin{array}{l}\text { Notice of Hainan Provincial Price } \\
\text { Bureau on Ledong Xiangshui } 20 \\
\text { MW photovoltaic power plant } \\
\text { electricity price }\end{array}$ & Supporting measures-GS & $\mathrm{PB}$ & Notices \\
\hline
\end{tabular}


Table A2. Cont.

\begin{tabular}{|c|c|c|c|c|c|}
\hline Num & Time & Policy Name & Policy Measure & Policy Department & Policy Type \\
\hline 304 & 2014.09 .26 & $\begin{array}{l}\text { Hainan Provincial Price Bureau } \\
\text { on the approval of the sea star } \\
\text { (Yangpu) aquatic food Co., Ltd. } \\
\text { rooftop photovoltaic power } \\
\text { generation project tariff notice }\end{array}$ & Supporting measures-GS & PB & Notices \\
\hline \multicolumn{6}{|c|}{ Chongqing province } \\
\hline 305 & 2009.05 .13 & $\begin{array}{l}\text { Notice on the declaration of solar } \\
\text { photovoltaic building } \\
\text { demonstration project }\end{array}$ & Supporting measures-FIS & $\mathrm{CC}$ & Notices \\
\hline 306 & 2009.07 .13 & $\begin{array}{l}\text { Notice on recollecting the } \\
\text { demonstration project of } \\
\text { renewable energy construction in } \\
\text { our city }\end{array}$ & Supporting measures-FIS & $\mathrm{CC}$ & Notices \\
\hline 307 & 2009.07.27 & $\begin{array}{l}\text { organization notice to declare the } \\
\text { construction of renewable energy } \\
\text { demonstration city }\end{array}$ & $\begin{array}{l}\text { Guidance measures-GD } \\
\text { Supporting measures-FIS }\end{array}$ & $\mathrm{CC}$ & Notices \\
\hline
\end{tabular}

Source: [33].

\section{References}

1. International Energy Agency Photovoltaic Power Systems Programme. Annual Report 2016. Available online: http://www.iea-pvps.org/fileadmin/dam/public/report/statistics/IEA-PVPS_-_A_ Snapshot_of_Global_PV_-_1992--2016_1_.pdf (accessed on 1 June 2017).

2. BP. BP Statistical Review of World Energy 2017 Underpinning Data. Available online: http:/ /www.bp.com/ statisticalreview (accessed on 1 June 2017).

3. Liu, D.; Shiroyama, H. Development of photovoltaic power generation in China: A transition perspective. Renew. Sustain. Energy Rev. 2013, 25, 782-792. [CrossRef]

4. Zhi, Q.; Sun, H.; Li, Y.; Xu, Y.; Su, J. China's solar photovoltaic policy: An analysis based on policy instruments. Appl. Energy 2014, 129, 308-319. [CrossRef]

5. Tour, A.D.L.; Glachant, M.; Ménière, Y. Innovation and international technology transfer: The case of the Chinese photovoltaic industry. Energy Policy 2011, 39, 761-770. [CrossRef]

6. Sun, H.; Qiang, Z.; Wang, Y.; Yao, Q.; Su, J. China's solar photovoltaic industry development: The status quo, problems and approaches. Appl. Energy 2014, 118, 221-230. [CrossRef]

7. Li, S.; Wang, J.; Liu, Q.; Li, L.; Hua, Y.; Liu, W. Analysis of Status of Photovoltaic and Wind Power Abandoned in China. J. Power Energy Eng. 2017, 5, 91-100. [CrossRef]

8. Grau, T.; Huo, M.; Neuhoff, K. Survey of photovoltaic industry and policy in Germany and China. Energy Policy 2012, 51, 20-37. [CrossRef]

9. Huo, M.L.; Zhang, D.W. Lessons from photovoltaic policies in China for future development. Energy Policy 2012, 51, 38-45. [CrossRef]

10. Zhang, S.; He, Y. Analysis on the development and policy of solar PV power in China. Renew. Sustain. Energy Rev. 2013, 21, 393-401. [CrossRef]

11. Zou, H.; Du, H.; Ren, J.; Sovacool, B.K.; Zhang, Y.; Mao, G. Market dynamics, innovation, and transition in China's solar photovoltaic (PV) industry: A critical review. Renew. Sustain. Energy Rev. 2017, 69, 197-206. [CrossRef]

12. Kayser, D. Solar photovoltaic projects in China: High investment risks and the need for institutional response. Appl. Energy 2016, 174, 144-152. [CrossRef]

13. Dusonchet, L.; Telaretti, E. Economic analysis of different supporting policies for the production of electrical energy by solar photovoltaics in western European Union countries. Energy Policy 2010, 38, 3297-3308. [CrossRef]

14. Sarasa-Maestro, C.J.; Dufo-López, R.; Bernal-Agustín, J.L. Photovoltaic remuneration policies in the European Union. Energy Policy 2013, 55, 317-328. [CrossRef]

15. Shrimali, G.; Jenner, S. The impact of state policy on deployment and cost of solar photovoltaic technology in the US: A sector-specific empirical analysis. Renew. Energy 2013, 60, 679-690. [CrossRef]

16. Sarzynski, A.; Larrieu, J.; Shrimali, G. The impact of state financial incentives on market deployment of solar technology. Energy Policy 2012, 46, 550-557. [CrossRef] 
17. Kwan, C.L. Influence of local environmental, social, economic and political variables on the spatial distribution of residential solar PV arrays across the United States. Energy Policy 2012, 47, 332-344. [CrossRef]

18. Zhang, S.; Zhao, X.; Andrews-Speed, P.; He, Y. The development trajectories of wind power and solar PV power in China: A comparison and policy recommendations. Renew. Sustain. Energy Rev. 2013, 26, 322-331. [CrossRef]

19. Zhang, M.; Zhou, D.; Zhou, P. A real option model for renewable energy policy evaluation with application to solar PV power generation in China. Renew. Sustain. Energy Rev. 2014, 40, 944-955. [CrossRef]

20. Zhao, X.; Zeng, Y.; Zhao, D. Distributed solar photovoltaics in China: Policies and economic performance. Energy 2015, 88, 572-583. [CrossRef]

21. Yuan, C.; Liu, S.; Yang, Y.; Chen, D.; Fang, Z.; Shui, L. An analysis on investment policy effect of China's photovoltaic industry based on feedback model. Appl. Energy 2014, 135, 423-428. [CrossRef]

22. Guo, X.; Guo, X.; Lund, H. China's photovoltaic power development under policy incentives: A system dynamics analysis. Energy 2015, 93, 589-598. [CrossRef]

23. Li, L.; Chi, T.; Zhang, M.; Wang, S. Multi-Layered Capital Subsidy Policy for the PV Industry in China Considering Regional Differences. Sustainability 2016, 8, 45. [CrossRef]

24. Rothwell, R.; Zegveld, W. Industrial Innovation and Public Policy: Preparing for the 1980s and the 1990s; F. Pinter: London, UK, 1981.

25. Gabriele, A. S\&T Policies and Technical Progress in China's Industry. Rev. Int. Political Econ. 2002, 9, $333-373$.

26. Su, Y.S.; Lin, C.J.; Li, C.Y. An assessment of innovation policy in Taiwan's electric vehicle industry. Int. J. Technol. Manag. 2016, 72, 210-229. [CrossRef]

27. Breslin, S. Foreign direct investment in the People's Republic of China: Preferences, policies and performance. Policy Soc. 2006, 25, 9-38. [CrossRef]

28. Huang, C. Organization, programme and structure: An analysis of the Chinese innovation policy framework. RED Manag. 2010, 34, 367-387.

29. Peng, J.S.; Sun, W.X.; Zhong, W.G. The evolution of Chinese technological and innovational policies and the empirical research on the performance (1978-2006). Sci. Res. Manag. 2008, 29, 134-150.

30. Wang, X.Z.; Peng, Z.G.; Gao, W.; Ji, S.B. The policy evolution and effect evaluation of wind power industry in China. Stud. Sci. Sci. 2016, 34, 1817-1829.

31. Schneider, A.; Ingram, H. Systematically Pinching Ideas: A Comparative Approach to Policy Design. J. Public Policy 1988, 8, 61-80. [CrossRef]

32. Peters, B.G. Policy Instruments and Public Management: Bridging the Gaps. J. Public Adm. Res. Theory 2000, 10, 35-47. [CrossRef]

33. The Law Information Database of Peking University. Available online: http://www.pkulaw.cn/ (accessed on 15 June 2017).

34. Menz, F.C.; Vachon, S. The effectiveness of different policy regimes for promoting wind power: Experiences from the states. Energy Policy 2006, 34, 1786-1796. [CrossRef]

35. Delmas, M.A.; Montes-Sancho, M.J. US state policies for renewable energy: Context and effectiveness. Soc. Sci. Electron. Publ. 2011, 39, 2273-2288.

(C) 2017 by the authors. Licensee MDPI, Basel, Switzerland. This article is an open access article distributed under the terms and conditions of the Creative Commons Attribution (CC BY) license (http://creativecommons.org/licenses/by/4.0/). 